\title{
Encephalitic Arboviruses: Emergence, Clinical Presentation, and Neuropathogenesis
}

\author{
Hamid Salimi ${ }^{1}$ • Matthew D. Cain ${ }^{1} \cdot$ Robyn S. Klein ${ }^{1,2,3}$
}

Published online: 24 May 2016

(C) The American Society for Experimental NeuroTherapeutics, Inc. 2016

\begin{abstract}
Arboviruses are arthropod-borne viruses that exhibit worldwide distribution, contributing to systemic and neurologic infections in a variety of geographical locations. Arboviruses are transmitted to vertebral hosts during blood feedings by mosquitoes, ticks, biting flies, mites, and nits. While the majority of arboviral infections do not lead to neuroinvasive forms of disease, they are among the most severe infectious risks to the health of the human central nervous system. The neurologic diseases caused by arboviruses include meningitis, encephalitis, myelitis, encephalomyelitis, neuritis, and myositis in which virus- and immune-mediated injury may lead to severe, persisting neurologic deficits or death. Here we will review the major families of emerging arboviruses that cause neurologic infections, their neuropathogenesis and host neuroimmunologic responses, and current strategies for treatment and prevention of neurologic infections they cause.
\end{abstract}

Keywords Arbovirus - Viral encephalitis · Innate immunity · Blood-brain barrier

Robyn S. Klein

rklein@dom.wustl.edu

1 Department of Internal Medicine, Washington University School of Medicine, St. Louis, MO, USA

2 Department of Pathology and Immunology, Washington University School of Medicine, St. Louis, MO, USA

3 Department of Neuroscience, Washington University School of Medicine, St. Louis, MO, USA

\section{Introduction to Encephalitic Arboviruses}

Arthropod-borne viruses (arboviruses) are transmitted to hosts during blood feeding of mosquitos, ticks, biting flies, mites, and nits. While the majority of arbovirus infections do not cause neuroinvasive disease, there are several arbovirus families with members that cause neuroinvasive disease in vertebrate hosts worldwide. The encephalitic members of the Togaviridae family alphaviruses (new-world group) consist of the Eastern, Western, and Venezuelan equine encephalitic viruses (EEEV, WEEV, and VEEV, respectively). The VEEV complex comprises 14 subtypes and varieties and includes 7 different virus species, while EEEV includes North and South American variants, with 4 major lineages [1]. Chickungunya virus (CHIKV) is another member of the Togaviridae family (old-world group) and Semiliki Forest virus complex that can cause central nervous system (CNS) disease [2]. Japanese encephalitis virus (JEV), West Nile virus (WNV), Saint Louis encephalitis virus (SLEV), and Murray Valley encephalitis virus (MVEV) comprise the Japanese encephalitis (JE) serogroup of neuropathogenic flaviviruses. Additional emerging mosquito-borne flaviviruses that can infect the CNS are dengue and Zika viruses (DENV and ZIKV, respectively). Arbovirus members of the Bunyaviridae family that cause neuroinvasive disease include viruses from 2 different genera, Orthobunyavirus and Phlebovirus. The Orthobunyaviruses California encephalitis virus (CEV) and La Crosse virus (LACV) are members of the California serogroup viruses, which include 15 related arboviruses that cause neuroinvasive and non-neuroinvasive diseases [3]. Toscana virus (TOSV) and Rift Valley fever virus (RVFV) belong to the genus Phlebovirus, which is predominately transmitted by sandfly and tick. Colorado tick fever virus (CTFV) is a neuroinvasive member of the Reoviridae that is transmitted by the Rocky Mountain wood tick. 


\section{Structural Aspects of Encephalitic Arboviruses}

Neuroinvasive arboviruses represent all 3 groups of RNA viruses (group III, IV, and V). Alphaviruses are enveloped viruses consisting of a positive, single-strand RNA genome (group IV) with 2 open reading frames that are translated into 2 polyproteins comprising structural and nonstructural proteins, respectively. Flaviviruses are similarly structured enveloped, positive single-strand RNA viruses. However, flaviviruses are translated from a single open reading frame into a polyprotein that is cleaved into mature structural and nonstructural polypeptides by viral and host proteases. While bunyaviruses also have spherical enveloped virions similar to alphaviruses and flaviviruses, Bunyaviruses are comprised of tripartite negative, single-strand RNA genomes (group V). The large, medium, and small segments are negative sense for orthobunyaviruses (CEV and LACV). However, the small segment is ambisense in the phleboviruses (TOSV and RVFV). As a group III virus, CTFV is the structurally most divergent neuroinvasive arbovirus. CTFV virions are nonenveloped and contain a double-strand RNA genome, which is divided into 12 segments. As such, each viral family utilizes distinct strategies for infection and replication. However, the common RNA composition of these viruses allows for higher rates of mutation, which results in diverse viral populations that both impedes development of effective vaccines and contributes to instances of viral emergence.

\section{Epidemiology of Encephalitic Arboviruses}

Encephalitic alphaviruses naturally cycle between mosquitoes and birds (EEEV and WEEV), mosquitoes and rodents (VEEV enzootic cycle), or mosquitoes and horses (VEEV epizootic cycle) [4]. VEEV, WEEV, and EEEV are all widely distributed in North, Central, and South America. Human infection can progress rapidly to encephalitis, with fatality rates of $\sim 1 \%$ in cases of VEEV and WEEV, and $50 \%$ to $75 \%$ in cases of EEEV cases $[5,6]$. Of the $3, \mathrm{VEEV}$ is considered the most important zoonotic pathogen, with several reported human outbreaks in South and Central Americas, primarily by enzootic VEEV strains [7]. VEEV outbreaks of enzootic strains in Central America have also been followed by spread to North America with occasional fatal human cases [8]. Within North America, the human cases per year are usually 1 to 2 for WEEV and 5 to 8 for EEEV; however, in 2005 there were 21 reported cases of EEEV [9]. Focal outbreaks of VEEV have occurred in North America, with epidemics of equine and human cases numbering in the hundreds, primarily in Mexico [10]. Although the overall number of human cases reported for these viruses is small, the possibility for disease emergence is high owing to expansion and spread of mosquito vectors. Additionally, there is the potential for even moderately experienced scientists to grow VEEV, WEEV, and/or EEEV to high titer and generate aerosol forms, which would cause severe disease if dispersed in a dense urban or military setting. Despite the epidemic potential of VEEV and the high morbidity and/or case fatality rates of EEEV and WEEV, there are no approved vaccines or therapeutics for humans.

CHIKV is a re-emerging alphavirus that can cause severe and fatal disease with CNS involvement of both adults and neonates [11-14]. Prior to its re-emergence in the Indian Ocean in 2004 and ensuing worldwide spread, CHIKV infections rarely involved the CNS. However, in recent major outbreaks of CHIKV in La Reunion Island and the Caribbean, the incidence of encephalitis is reportedly 187 per 100,000 infants and 37 per 100,000 persons for adults $>64$ years of age [15].

JE serogroup flaviviruses cycle between birds and mosquitoes, and cause neurologic infections in humans, whose incidences depend on age and immune status. WNV, which was first identified in the West Nile subregion of Uganda, is now endemic in temperate and tropical regions throughout the world, causing yearly outbreaks of encephalitis, with a mortality rate of $5 \%$ to $10 \%$ [16]. MVEV causes similar outbreaks in Australia, New Guinea, and New Zealand, while SLEV rarely causes encephalitis in the USA $(<10$ cases per year) $[16,17]$. JEV is the most medically important member of the serogroup, causing 30,000 to 50,000 cases of encephalitis and 10,000 deaths each year in Asia [18]. While these viruses are generally transmitted via ornithophilic mosquitoes, WNV has also been transmitted via blood products, and both WNV and JEV can be transplacentally transmitted during pregnancy $[19,20]$. JEV and MVEV predominantly cause encephalitis in children, whereas encephalitis due to WNV or SLEV is more likely to occur in adults. DENV, which is endemic to $>100$ countries, has been reported to cause encephalitis in up to $41 \%$ of cases [21].

ZIKV is a related, mosquito-transmitted flavivirus, first isolated from a febrile rhesus macaque in Uganda in 1947, which has emerged from obscurity to cause outbreaks in Micronesia, French Polynesia, and South and Central America [22, 23]. In adults, ZIKV infection results in a selflimiting febrile illness associated with rash and conjunctivitis, but severe neurologic disease can occur, including GuillainBarré syndrome (GBS) and meningoencephalitis [24, 25]. The current ZIKV outbreak in South America has been associated with a 20 -fold increase in the rate of babies born with microcephaly $[22,26]$, and spontaneous abortion or intrauterine growth restriction due to placental insufficiency [27]. Since 2007, 55 countries in America, Asia, Africa, and Oceania have detected local transmission of the virus, affecting $>1.5$ million people [28]. In the USA and its territories, $>1025$ cases have been reported [29]. Cases of sexual transmission of ZIKV and detection of persistent infectious ZIKV in semen have also been reported [30-33]. 
Bunyaviruses exhibit a diversity of enzootic cycles. Mosquito-borne bunyaviruses include CEV and LACV, which are endemic to the western and mid-west/eastern USA, respectively, and cycle between mosquito and small mammals. CEV and LACV cause an average of 75 cases of meningitis, encephalitis, or meningoencephalitis per year with the majority of disease due to LACV [34]. RVFV has caused periodic outbreaks in Kenya, Somalia, Tanzania, Saudi Arabia, and Yemen [35]. Outbreaks in endemic areas have occurred with up to 20,000 cases and $>500$ deaths [36]. RVFV is spread via mosquitoes or through extensive contact with blood, milk, and body tissues from infected livestock [37]. TOSV is transmitted by sandflies and causes 100 to 200 cases of meningoencephalitis each summer in Europe and North Africa [38]. Although the natural reservoirs for TOSV remain unidentified, canines have been identified as potential candidates [39].

CTFV primarily cycles between multiple species of rodents and Rocky Mountain wood ticks [40, 41]. CTFV causes symptomatic illnesses in all cases and occurring exclusively in the western parts of the USA and Canada [42]. A total of 83 cases occurred between the years 2002 and 2012 [43].

\section{Clinical Features of CNS Infections with Arboviruses: Human Disease}

Infections with arboviruses vary in clinical presentation from completely asymptomatic to florid encephalitis with seizures, coma, and death (Table 1). In general, symptomatic patients will initially develop a flu-like illness with headache, fever, pharyngitis, and myalgia. Depending on the virus, this may progress to nausea, vomiting, and meningismus, or undergo initial resolution followed by recrudescence of headache and fever that rapidly progresses to neurologic symptoms. Although multiple neurotropic arboviruses are endemic in the USA, including CEV, LACV, WNV, SLEV, VEEV, WEEV, DENV, CHIKV, ZIKV, and CTFV, symptomatic infections of the CNS are rare. Meningitis and encephalitis are the most common manifestations of neuroinvasive diseases with any of these viruses. In this section, we will provide a detailed review the clinical features of CNS infections with arboviruses that occur worldwide.

\section{Togaviridae}

Natural or laboratory-acquired infections have been documented in humans with all epizootic and many enzootic VEEV strains [44]. After a 2 to 4 day incubation period, all patients develop an incapacitating illness with high fever, headache, pharyngitis, malaise, and myalgia. Laboratory evaluation reveals lymphopenia and elevation in hepatic enzymes. This acute phase typically lasts 24 to $48 \mathrm{~h}$ and is followed by a 2 to 3 -week period of lethargy and anorexia. In a small percentage of cases $(0.05-4 \%)$, patients develop encephalitis, which occurs a few days after the acute febrile illness [45]. The overall mortality of encephalitis varies with age; the mortality rate is approximately $20 \%$ in older children and young adults but may reach $35 \%$ in persons aged 0 to 5 years [46]. The neuropathologic and neuroimmunologic effects of VEEV in human encephalitis cases have not been well described owing to lack of autopsy specimens. Gross pathologic analysis of 21 lethal encephalitis cases revealed cerebral edema and meningeal infiltrates comprised of neutrophils, lymphocytes, and monocytes that extend to Virchow Robbins spaces and, in some cases, CNS parenchyma [47].

Most human infections with EEEV are asymptomatic; however, neuroinvasive forms of infection results in a higher mortality rate and more severe neurologic sequelae. Following an incubation period of 5 to 15 days, infection may progress to systemic then encephalitic disease [5]. Systemic disease presents with headache, fever, malaise, myalgia, nausea, and vomiting. Encephalitis additionally results in photophobia, confusion, somnolence, focal neurologic deficits, paresis, paralysis, respiratory impairment, seizures, and coma, which may persist if the patient survives the acute illness. However, in many cases (36-75\%) death occurs 2 to 10 days after onset of symptoms [9]. The mortality rate is highest (50$75 \%$ ) in patients $>60$ years of age with cognitive impairment occurring in 30 to $70 \%$ of survivors [5]. Neuropathologic findings include neuronal injury with caspase 3 activation, vasculitis and thrombosis, demyelination, necrosis, and meningeal, perivascular, and parenchymal infiltrates comprised of neutrophils, lymphocytes, and monocytes/macrophages [48]. Brain lesions in fatal cases occur predominantly within the basal ganglia, thalamus, and brainstem.

WEEV infection results in more mild disease than EEEV. Most vector-borne WEEV infections are asymptomatic or present as a nonspecific febrile illness. The incubation period is 5 to 10 days, with a short prodromal phase lasting approximately 1 to 4 days. However, the signs and symptoms of encephalitic WEEV are similar to those described for VEEV and EEEV. These signs include somnolence, seizures, coma, and motor neuron dysfunction [6]. The mortality rate in human WEEV encephalitis ranges from $3 \%$ to $15 \%$, depending on age and, possibly, viral factors [49]. Unlike vector-borne infections, where virus is deposited subcutaneously, the process of neuroinvasion by aerosolized alphaviruses is more direct, via the olfactory tract, and causes increased severity and incidence of encephalitis [50]. For example, a laboratory accident resulting in aerosolization and exposure to WEEV resulted in encephalitis with a mortality of $40 \%$ [51]. Similar to VEEV and EEEV, neurologic sequelae of WEEV encephalitis may persist for months to years or be permanent, and postmortem brain specimens of fatal cases exhibit perivascular cuffs of lymphocytes and 


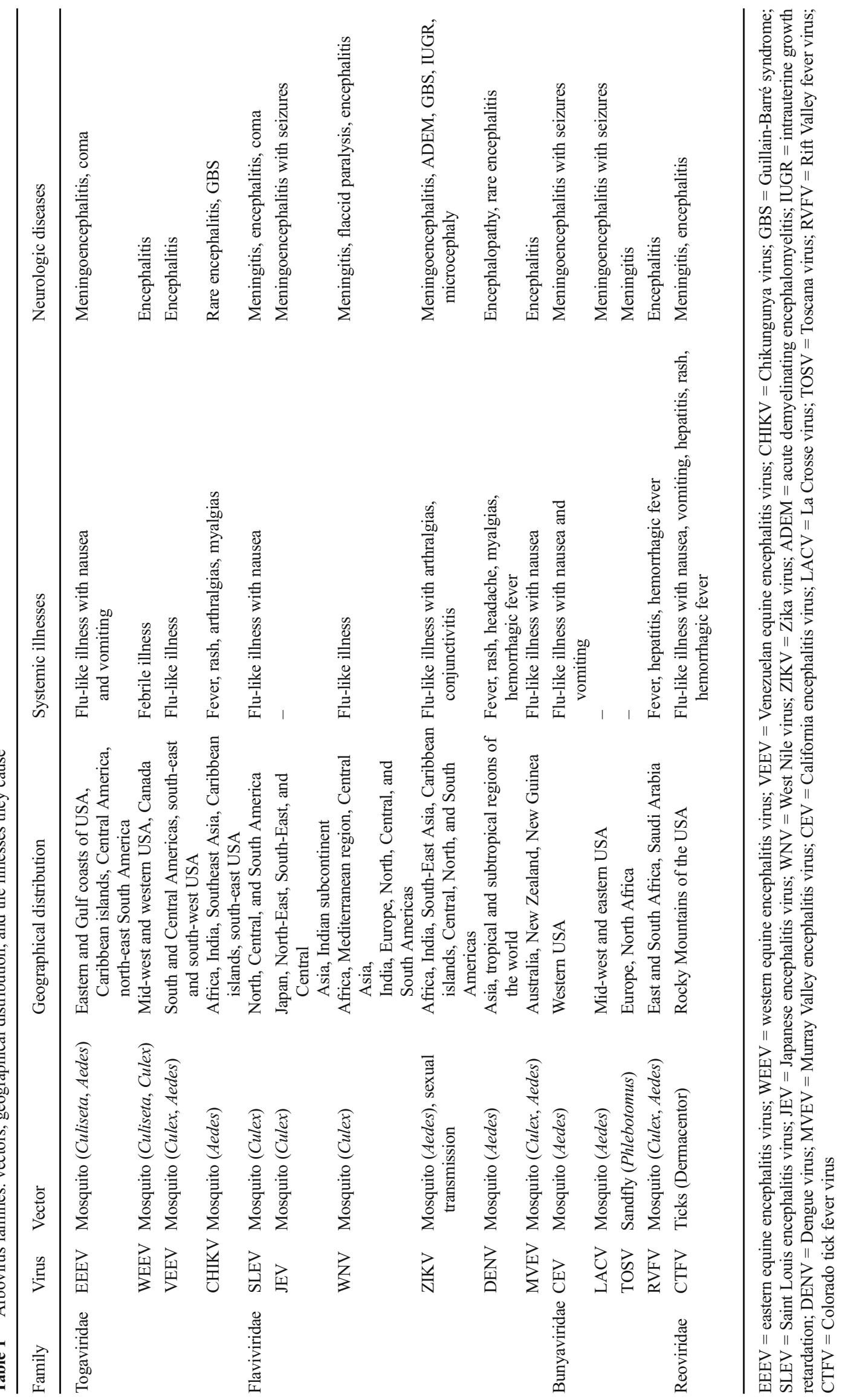


neutrophils, multifocal necrosis, and gliosis throughout the basal ganglia, thalamus, and brainstem [48].

CHIKV infection predominantly results in an acute illness with high fever and severe arthralgias lasting weeks to months but sometimes for years [52, 53]. However, severe and fatal disease with CNS involvement in both adults and neonates has been reported and include encephalitis and postinfectious syndromes, including acute demyelinating encephalomyelitis and GBS [11-15]. Neonatal infections occur via vertical transmission during pregnancy or at birth [54].

\section{Flaviviridae}

Most individuals infected with flaviviruses are asymptomatic; however, up to $25 \%$ of infections may present with symptomatic disease that is mild or neuroinvasive [55]. JEV and MVEV cause mild, febrile illnesses in a majority of symptomatic patients, with only 1 in 250 patients developing meningoencephalitis characterized by the rapid onset of high fever, headache, neck stiffness, disorientation, coma, seizures, spastic paralysis, movement disorders, and, in $30 \%$ of cases, death. Of those who survive, $20 \%$ to $30 \%$ exhibit persistent motor and/or cognitive deficits with recurrent seizures [56, 57]. These illnesses occur in a bimodal distribution, affecting the very young or nonimmune visitors to endemic regions, and the elderly, whose immunity has waned. The neuropathology of JEV and MVEV involves neuronal damage and inflammatory infiltrates, and viral antigen may be detected within neurons of the thalamus, hippocampus, substantia nigra and medulla oblongata [58, 59].

In contrast, SLEV and WNV cause symptomatic infections in adults, especially those that are chronically ill, immunosuppressed, or elderly. In the USA, WNV transmission has also occurred through infected organ transplants and blood products $[60,61]$, necessitating massive screening practices. Half of symptomatic infections are limited to a febrile illness with pharyngitis, myalgia or arthralgia, and rash [62]. Neurologic diseases occur in the remainder, and depend on the site of infection within the CNS. Thus, patients can present with meningitis, encephalitis, or myelitis with flaccid paralysis [63]. Patients with encephalitis may present with seizures, movement disorders, or diaphragmatic paralysis necessitating permanent dependence on mechanical ventilation [64, 65]. Neuropathologic findings include perivascular and leptomeningeal inflammation, microglial nodules, and neuronophagia, predominantly involving the temporal lobes and brainstem. These findings may also occur in the spinal cord $[62,66,67]$.

Primary infection with DENV causes a self-limited, acute febrile illness with headache, malaise, retro-orbital pain, myalgia, arthralgia, and a generalized, maculopapular rash [68]. Dengue hemorrhagic fever (DHF) results from secondary infection and is characterized by a recurrent high fever with vascular leak causing widespread bleeding and multisystem disorder. Presentations of CNS disorder were therefore initially attributed to DHF; however, recent studies indicate that patients with DHF infection may present with acute encephalitis, GBS, and polyradiculopathy, and that DENV is directly neurotropic [68-71].

Prior to the current outbreak, ZIKV infections in humans were reportedly mild, with $70 \%$ to $80 \%$ of infections being asymptomatic [72]. Clinical symptoms, when present, are similar to a flu-like illness with fever, maculopapular rash, nonpurulent conjunctivitis, fatigue, and arthralgia, and last approximately 1 week [73]. However, since 2007, an increase in cases of microcephaly, retinal lesions, and GBS associated with ZIKV infection has been reported, especially in Latin America [27, 74-76]. ZIKV-associated GBS is a pure motor axonal variant. Infection in pregnant women causes catastrophic fetal abnormalities, including microcephaly, spontaneous abortion, and intrauterine growth restriction due to placental insufficiency [27]. Newborns with microcephaly typically have significant neurologic defects and seizures, with variable effects on developmental milestones and cognitive abilities [77, 78].

\section{Bunyaviridae}

Encephalitides due to CEV and LACV occurs after initial incubation periods of 3 to 7 and 5 to 15 days, respectively. Both initially present as a summertime febrile illness with headache, nausea, vomiting, abdominal pain, and lethargy [3]. Encephalitis is characterized by fever, focal neurologic abnormalities with altered mental status that can progress to seizures and coma. However, the mortality rate is $<1 \%$. Severe illness is more common in young children and $20 \%$ may continue to have seizures after recovery. The low incidence and mortality rate has led to a lack of autopsy specimens for neuropathologic analyses.

Most RVFV infections are asymptomatic or cause a mild febrile illness with headache, myalgias, and mild hepatitis. In $<2 \%$ of symptomatic cases, the illness progresses to hemorrhagic fever, meningoencephalitis, and/or necrotizing retinitis leading to blindness [37]. While the overall mortality rate for severe RFVF infections is $<1 \%$, it may approach $50 \%$ in hemorrhagic cases. Neuropathologic findings include diffuse perivascular infiltrates of lymphocytes and macrophages, multifocal meningitis, and focal areas of neuronal necrosis and aggregates of macrophages, lymphocytes, and neutrophils throughout all regions of the brain [79].

Similar to other members of the Bunyaviridae, TOSV infection is generally asymptomatic or causes a flu-like, febrile illness with headache and myalgia, mostly in younger people [38]. This newly emerging pathogen causes outbreaks of meningitis and meningoencephalitis mostly in older individuals. There have also been reports of severe cases complicated by 
hydrocephalus, deafness, and ischemic events [38]. Neuropathologic studies have been performed in a single lethal case of meningoencephalitis and showed extensive perivascular and parenchymal infiltration of CD8 T cells with microglial activation in a variety of CNS regions, including the neocortex, basal ganglia, hypothalamus, thalamus, limbic areas and brain stem, and infiltration of immune cells within the meninges [80].

\section{Reoviridae}

After CTFV infection, the virus may persist in the bloodstream for up to 4 months, which has previously led to transfusion-acquired infections [81]. Persons infected with CTFV usually exhibit signs and symptoms within 3 to 6 days of a tick bite [82]. The illness is two staged, with an initial episode of fever, chills, headaches, photophobia, myalgia, malaise, abdominal pain, hepatosplenomegaly, nausea and vomiting, and a rash. The second stage is heralded by a high fever with return of symptoms and an increase in their severity with progression to meningitis, meningoencephalitis, or hemorrhagic fever. Children may exhibit the most severe symptoms and require extended hospitalization; death is extremely rare [82].

\section{Recovery from Arbovirus Encephalitis}

Survivors of arbovirus encephalitis may continue to exhibit significant neurocognitive deficits that persist for years after clearance of virus. For example, studies evaluating the rates of persistent impairment in patients previously diagnosed with WNV encephalitis via serum or cerebrospinal fluid (CSF) IgM using memory (Hopkins Verbal Learning Test) and visuospatial (Rey Complex Figure Copy and Recall) tests report that $40 \%$ to $70 \%$ exhibit cognitive symptoms for up to 5 years after the episode of acute infection [83-93]. Thus, for WNV encephalitis, at a $>90 \%$ rate of survival with $\sim 50 \%$ incidence of cognitive disturbance, there are currently approximately 10 , 000 people living with this sequelae of neuroinvasive WNV infections, with additional cases occurring at rates of 1000 to 3000 per year. Additional encephalitic arboviruses that lead to neuroinvasive disease with neurocognitive sequelae in American patients include SLEV, LACV, EEEV, and Powassan virus, with total case numbers in the hundreds [94-97]. Finally, worldwide, encephalitic arboviruses, including JEV and RVFV, cause neurologic illness at the rate of 50 to 100,000 cases/year with neurocognitive sequelae in survivors [98-100]. There are currently no diagnostic or treatment modalities for cognitive sequelae in patients that recover from arbovirus encephalitides.

\section{Mechanisms of Peripheral Infection, Pathogenesis, and Host Defense}

While the pathogenesis of arboviruses in humans has not been extensively explored, the use of animal models has elucidated conserved mechanisms and strategies in both arbovirus infection and host defense. During the course of a mosquito or tick bite up to $10^{6}$ plaque-forming units of virus can be transferred into the host [101]. In experimental models, animals receive viral inoculum subcutaneously to mimic arthropod-borne infection. During the early phase of infection, arboviruses undergo an initial period of replication in the skin. Flaviviruses, such as WNV, replicate in both keratinocytes and skin dendritic cells (DCs), including Langerhans cells [102-104]. Infected DCs migrate to draining lymph nodes, leading to an additional round of infection and subsequent entry into the circulation via efferent lymphatic system and the thoracic duct. Similar early replication and trafficking to draining lymph nodes has been observed in VEEV [105]. However, EEEV, a related alphavirus, does not replicate readily in lymphoid tissues but instead replicates in fibroblasts before targeting osteoblasts $[106,107]$.

Once in the blood, infection spreads to visceral organs, including the spleen and kidney. The specific cellular targets in these tissues are not well identified, but likely targets are subsets of DCs, macrophages, and neutrophils [108-110]. The level of viremia has been shown to correlate with the viral dissemination to the CNS [111]. Therefore, the early immune responses may be critical to limiting the neuropathogenesis of neurotropic virus.

Infection of leukocytes within secondary lymphoid tissues leads to activation of the innate immune response, including antiviral cytokine expression, expansion of leukocytes, antigen processing, and presentation to T cells. Pathogenrecognition receptors (PRRs) in infected cells recognize pathogen-associated molecular patterns associated with RNA viruses at multiple stages during the replication cycle. Endosomal nucleic acids sensors Toll-like receptor (TLR)3 and TLR7 are capable of sensing viral double-stranded RNA and single-stranded RNA, respectively, during cell entry, while the cytoplasmic double-stranded RNA sensors, retinoic-acid inducible gene I (RIG-I) and melanoma differential-associated gene 5 (MDA5) can identify viral RNA products during replication. RIG-I and MDA5 have been demonstrated to recognize WNV and VEEV in vitro. Although their role in shaping VEEV infection in vivo has not been explored [112, 113], RIG-I and MDA5 are essential for control of WNV replication in the periphery. Mice lacking mitochondrial antiviral-signaling protein (MAVS), the central adaptor to both RIG-I and MDA5 signaling, exhibited increased viremia and viral load in peripheral tissues [114]. However, MDA5 itself has been demonstrated to play a limited role in controlling WNV replication in the periphery 
[115]. Ablation of TLR3 results in mildly increased WNV burden in peripheral tissues $[116,117]$. However, these studies have described opposing phenotypes regarding survival during WNV infection of $\mathrm{TLR} 3^{-/-}$mice. TLR7 $7^{-1-}$ mice are more vulnerable to WNV infection and exhibit increased viremia, independently of regulation of cytokine expression [118]. For the bunyavirus, LACV, both endosomal cytosolic PRRs are necessary for survival and type 1 interferon (IFN) production [119].

The type I IFN response is a critical component of the regulation of viral infection. Ablation of the IFN- $\alpha / \beta$ receptor results in enhanced lethality in many arboviruses, including WNV [120, 121], VEEV [122-124], and LACV [125, 126]. Additionally, exogenous IFN- $\alpha$ promotes survival by inhibiting peripheral replication of WNV and VEEV [127, 128]. Activation of PRRs results in activation of IFN regulatory factors (IRFs) 3 and 7, expression of type 1 IFNs, IFN- $\alpha$ and, IFN- $\beta$, which induce the expression of IFN-stimulated genes (ISGs). Several antiviral ISGs, including protein kinase RNA-activated (PKR), 2'5'-oligoadenylate synthase (OAS), members of the poly (ADP-ribose) polymerase family and IFN-induced transmembrane protein family members have global effects on the cell in order to restrict viral replication. PKR inhibits both host and viral translation by regulating eIF$2 \alpha$. Viremia is increased in $\mathrm{PKR}^{-/-}$mice, an effect that is independent of PKR-dependent augmentation of IFN expression [110, 129]. OAS generates 2'5'-oligoadenylates to activate RNase $\mathrm{L}$ to degrade viral and cellular RNAs. RNaseL ${ }^{-/}$ mice exhibit higher WNV viral loads in peripheral tissues. Members of the poly (ADP-ribose) polymerase family block translation and replication of VEEV [130, 131]. IFN-induced transmembrane protein family members play a key role in limiting bunyavirus, including RVFV and LACV, replication by inhibiting viral membrane fusion in the endosome [132].

The innate immune response is critical for the limitation of viral propagation, especially during early infection. However, viral clearance in the periphery is dependent on the adaptive immune response. Both $\mathrm{T}$ and $\mathrm{B}$ lymphocytes are critical, as severe combined immunodeficiency, RAG1, or B cell-deficient, $\mu \mathrm{MT}$ mice all exhibit enhanced lethality to both WNV and VEEV $[133,134]$. Activation of B cells by infected DCs within lymph nodes induces neutralizing antibody responses, which is critical for viral clearance in the periphery [135]. Specifically, it is $\operatorname{IgM}$ that is essential for clearance of WNV or VEEV from the blood [136]. IgG is more critical for limiting dissemination and clearance from infected tissues.

Type II IFN (IFN- $\gamma$ ), which is produced by $\gamma \delta$ T cells, CD 8 $\mathrm{T}$ cells and natural killer cells, also exerts an antiviral role in the periphery. Mice lacking IFN- $\gamma$ or IFN- $\gamma$ receptor exhibit increased viremia and viral burdens in lymphoid tissues leading to early CNS invasion and decreased survival [137]. Similarly, $\gamma \delta \mathrm{T}$ cells, in part through action as IFN- $\gamma$ producers, are necessary to limit WNV viremia [138]. However, in an intranasal inoculation model of WNV-induced seizures, IFN- $\gamma$ was immunopathogenic, as IFN- $\gamma^{-/-}$mice displayed resistance to induction of limbic seizures.

\section{Entry of Arboviruses into the CNS}

Shortly after viremia, arboviruses enter the CNS via several mechanisms, depending on host and viral factors. Despite years of intensive research, the exact mechanisms by which arboviruses enter the CNS remain unclear. However, several pathways have been described as outlined below (Fig. 1).

Arboviral infections typically occur in highly enervated dermis, which may lead to viral entry into the CNS through peripheral neurons. Both in vitro and in vivo studies have shown that WNV can spread along neurons via retrograde axonal microtube-mediated transport [139, 140]. Indeed, intrasciatic inoculation of hamsters with WNV resulted in infection of spinal cord and acute flaccid paralysis. Similarly, pretreatment of mice with nocodazole, a microtubule destabilizing agent, delayed WNV infection of the brain, further supporting the involvement of retrograde axonal transport in CNS invasion [141].

CNS invasion via olfactory bulb has been demonstrated for several encephalitic arboviruses, including SLEV [142], MVEV [143], VEEV [144], EEEV [145], and LACV [146]. Soon after onset of viremia, viral particles exit the fenestrated capillaries beneath the mucosa of the nasal cavity. There, they are directly exposed to olfactory sensory neurons (OSNs), which are highly susceptible to infection. OSNs reside in the olfactory neuroepithelium with dendritic terminals that project into the nasal cavity and axonal projections that extend the cribiform plate into the glomerular structures of the olfactory bulb, thereby providing an axonal pathway for neurotropic viruses to gain access to the CNS. Infection of OSNs is followed by viral spread into the olfactory bulb via the anterograde axonal pathway $[142,144]$. Once inside the olfactory bulb, the virus disseminates rapidly to the brain tissues. Importantly, previous reports have shown that VEEV and EEEV infection of nonhuman primates through the aerosol pathway does not require development of viremia for neuroinvasion [147, 148].

CNS infection by arboviruses typically occurs shortly after viremia, suggesting the bloodstream as a critical route for CNS entry across the blood-brain barrier (BBB). The BBB is a tightly regulated interface that separates the CNS from the circulating blood. This barrier is composed of a basal membrane, brain microvascular endothelial cells (BMECs), with extensive tight junctions (TJs) and adherens junctions, which are ensheathed by pericytes and astrocyte end-feet [149]. Virus may enter via either direct infection of BMECs, passive diffusion through the BBB, transcellular transport through BMECs, or by paracellular migration between endothelial 


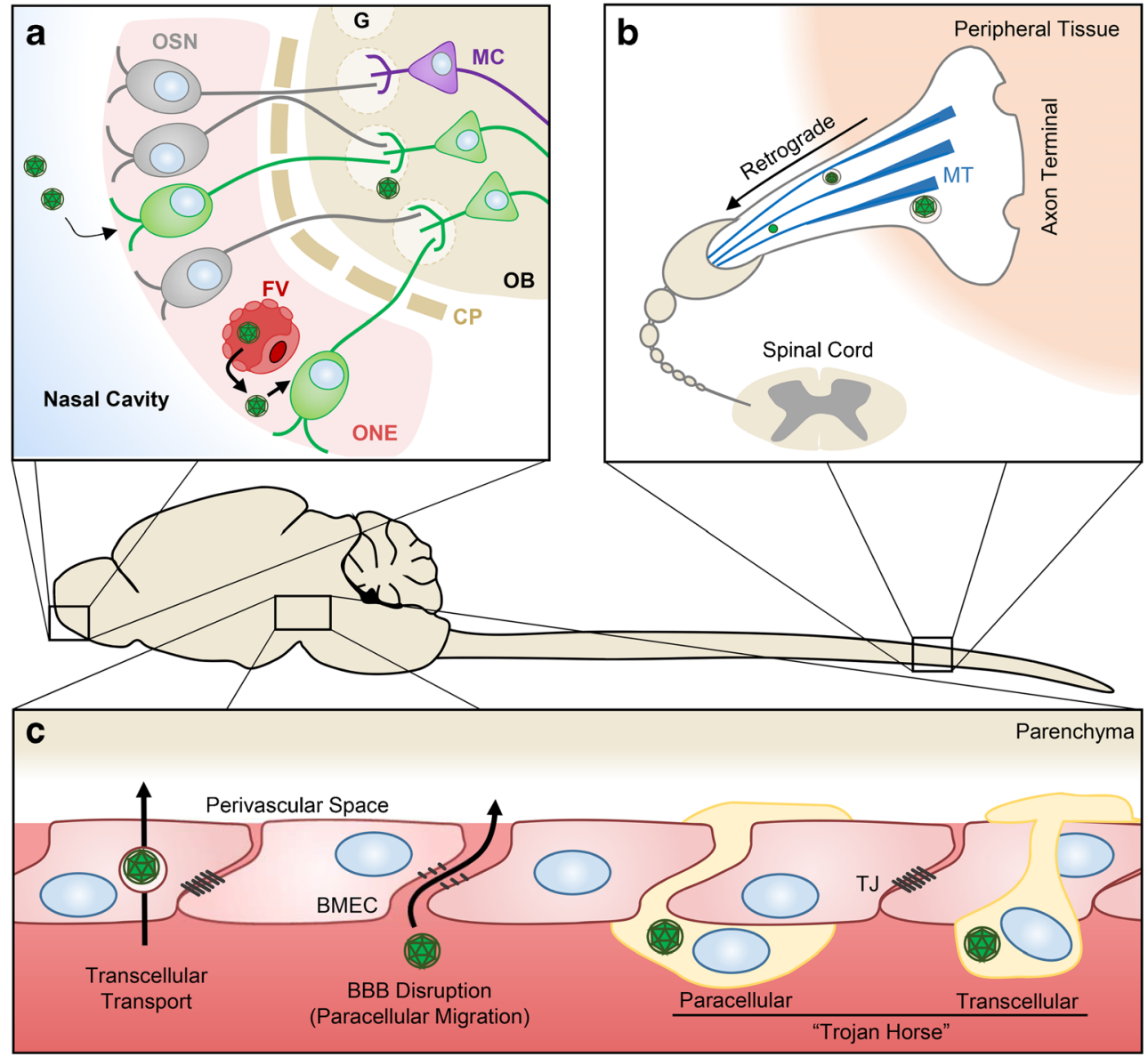

Fig. 1 Routes of arbovirus entry into the central nervous system (CNS). (A) Infection of olfactory sensory neurons (OSN) in the olfactory neuroepithelium (ONE) following intranasal inoculation or ONE infection from fenestrated vessels (FV). CNS entry occurs after viral migration through the cribiform plate (CP), subsequent infection of mitral cells (MC) at the glomeruli $(\mathrm{G})$ of the olfactory bulb $(\mathrm{OB})$, and dissemination along neuronal tracts. (B) Retrograde transport of virus along axon microtubules

TJs after BBB disruption. Although BMECs have been shown to be infected by several encephalitic arboviruses in vitro [150-152], there is no strong evidence of arboviral infection of BMECs in vivo, indicating that BMEC infection is not necessary for entry to the CNS $[153,154]$. Passive diffusion of virus across the BBB has been proposed previously; yet, convincing evidence to support this hypothesis has still to be demonstrated. However, WNV is transcellularly transported from the apical to basolateral side of murine BMECs in vitro, independently of replication and without impairing the integrity of TJs $[150,155]$. Likewise, ultrastructural studies in infected mice revealed JEV within endocytic vesicles of BMECs [156].

Paracellular entry of virus may occur following disruption of the TJs of the BBB. In a model of WNV infection using insect cell-derived WNV, BBB disruption coincided with peripheral infection and preceded CNS entry $[152,157]$. However, recent studies using mice infected with JEV [151],
(MT) of peripheral neurons facilitates entry into the CNS at the spinal cord. (C) Virus entry through the blood-brain barrier (BBB) is dependent on transcellular transport by brain microvascular endothelial cells (BMECs) of virions or paracellular migration of virions following disruption of tight junctions (TJ). Infected leukocytes may also facilitate CNS entry via paracellular or transcellular extravasation - the "Trojan Horse" model $\mathrm{FV}=$ fenestrated vessel; $\mathrm{BMEC}=$ brain microvascular endothelial cells

WNV [158, 159], and tick-borne encephalitis virus (TBEV) [160] have demonstrated that CNS entry of virus can occur before BBB disruption. Paracellular entry under these conditions may contribute to a second phase of CNS infection. Indeed, initial infection of CNS by VEEV via the olfactory route impairs the BBB leading to a CNS infection through hematogenous spread [161]. This observation was further supported by other studies where intracranial inoculation of mice with VEEV replicon particles resulted in increased expression of intercellular adhesion molecule 1 (ICAM-1) on BMECs, followed by BBB disruption [162].

An alternative pathway of CNS infection is the "Trojan horse" model in which infected leukocytes cross the BBB, thereby delivering virus into the CNS. Under normal conditions, BMECs express very low levels of leukocyte adhesion molecules (i.e., platelet endothelial cell adhesion molecule 1, ICAM-1 and vascular cell adhesion protein 1). However, infection with alphaviruses and flaviviruses upregulates BMEC 
expression of these adhesion molecules [151, 163, 164], promoting extravasation of leukocytes into the CNS. Consistent with this notion, increased expression of ICAM-1 has been shown to precede CNS invasion of mice infected with WNV [165]. Additionally, mice deficient in ICAM-1 displayed decreased CNS viral loads, diminished neuronal damage, and reduced BBB permeability following infection with WNV [166]. The Trojan horse model has also been suggested for JEV [167, 168]. Nonetheless, whether infected leukocytes maintain their function to migrate into the CNS remains controversial, as no ultrastructural evidence of virus infection was observed in infiltrating leukocytes after infection with MVEV, a zoonotic flavivirus [169]. Collectively, the abovementioned studies suggest that disruption of BBB can be a prerequisite for or a consequence of CNS infection, and that arboviruses seem to utilize multiple pathways for CNS entry, depending on virus, route of infection, dose, and age.

\section{Neuropathogenesis of Arboviruses}

Within the CNS, neurons are the main target cells for encephalitic flaviviruses [154, 170], alphaviruses [107, 145], and members of the Bunyaviridae and Reoviridae [146, 171, 172]. Arboviral infection of other cell types of the CNS has also been reported (Table 2), and recent in vitro studies with ZIKV suggest it may target neural progenitor cells [173-176]. RNA of ZIKV has also been detected in samples of brain tissue, placenta, and amniotic fluid of newborns with microcephaly and in the stillborn infants of women infected by Zika during pregnancy [28].

The envelope protein of encephalitic arboviruses is the major determinant of neurotropism and neurovirulence, owing to its role in receptor binding and virus entry [177-179]. However, sequence analysis of virulent and attenuated strains of these viruses revealed that other regions of the viral genome, including the 3 ' untranslated region and nonstructural proteins, also contribute to neurovirulence and viral tropism [180].

Arboviral neuropathogenesis involves two distinct features: neuroinvasiveness and neurovirulence. Neuronal damage and loss can occur by either direct arboviral infection or indirectly by uncontrolled immune responses to the replicating virus [181, 182]. In vitro and in vivo studies have shown that neurons undergo morphologic changes that are characteristic of apoptosis, that is, nuclear and membrane condensation, after infection with several encephalitic flaviviruses, including WNV [183], JEV [154], TBEV [184], and alphaviruses [145, $185,186]$. Neuronal degeneration, necrosis, and apoptosis were also demonstrated in various CNS regions in mice infected with LACV [146].

Several mechanisms appear to be involved in the induction of apoptosis by encephalitic arboviruses. For instance, WNV and JEV induce neuronal apoptosis through caspase-3 and Bax signaling pathways [154, 187], depending on brain region or viral strain [187]. Indeed, mice lacking caspase-3 displayed

Table 2 Susceptibility of central nervous system cells to infection by encephalitic arboviruses

\begin{tabular}{|c|c|c|c|c|c|c|c|c|c|}
\hline & \multicolumn{2}{|l|}{ Neurons } & \multicolumn{2}{|c|}{ Astrocytes } & \multicolumn{2}{|c|}{ Microglia } & \multicolumn{2}{|l|}{ BMECs } & \multirow[t]{2}{*}{ References } \\
\hline & In vitro & In vivo & In vitro & In vivo & In vitro & In vivo & In vitro & In vivo & \\
\hline \multicolumn{10}{|c|}{ Flaviviruses } \\
\hline WNV & Yes & Yes & Yes & No & Yes & No & Yes & No & {$[152,286,287]$} \\
\hline JEV & Yes & Yes & Yes & Yes & Yes & Yes & Yes & Yes/no & {$[151,288-290]$} \\
\hline SLEV & Yes & Yes & NIA & Yes & NIA & Yes & NIA & No & {$[142,291,292]$} \\
\hline TBEV & Yes & Yes & Yes & No & Yes & NIA & NIA & No & {$[198,241,293]$} \\
\hline MVEV & Yes & Yes & No & No & No & No & No & No & {$[143,294]$} \\
\hline \multicolumn{10}{|c|}{ Togaviridae } \\
\hline VEEV & Yes & Yes & Yes & Yes & NIA & Yes & NIA & No & {$[185,204,295,296]$} \\
\hline EEEV & NIA & Yes & NIA & Yes & NIA & Yes & NIA & No & {$[107,145,297]$} \\
\hline \multicolumn{10}{|c|}{ Bunyaviridae } \\
\hline LACV & Yes & Yes & NIA & Yes & NIA & Yes/no & NIA & No & {$[146,218,298]$} \\
\hline RVFV & Yes & Yes & NIA & Yes & NIA & Yes & NIA & No & [299-301] \\
\hline \multicolumn{10}{|c|}{ Reoviridae } \\
\hline CTFV & NIA & Yes & NIA & NIA & NIA & NIA & NIA & NIA & {$[171]$} \\
\hline POWV & Yes & Yes & NIA & Yes & NIA & Yes & NIA & No & {$[172,302,303]$} \\
\hline
\end{tabular}

BMECs = brain microvascular endothelial cells; WNV = West Nile virus; JEV = Japanese encephalitis virus; SLEV = Saint Louis encephalitis virus; NIA = no information available; TBEV = tick-borne encephalitis virus; MVEV = Murray Valley encephalitis virus; VEEV = Venezuelan equine encephalitic virus; $\mathrm{EEEV}=$ Eastern equine encephalitic virus; $\mathrm{LACV}=\mathrm{La}$ Cross virus; $\mathrm{RVFV}=\mathrm{Rift}$ Valley fever virus; $\mathrm{CTFV}=\mathrm{Colorado}$ tick fever virus; POWV = Powassan encephalitic virus 
reduced neuronal death compared with wild-type mice, despite having comparable viral loads in their brain [183]. Similarly, inhibition of caspase activity reduced WNVmediated neuronal death in primary neuronal culture [183]. Both structural and nonstructural proteins of flaviviruses were involved in caspase-mediated neuronal apoptosis [188-190]. A second mechanism of neuronal apoptosis involves RIG-Ilike receptor (RLR) signaling. While RLR-induced activation of MAVS exhibits antiviral activity [191], it can cause neuronal death by triggering sterile alpha and TIR motif-containing 1 (SARM1) protein [192]. In this regard, mice lacking SARM-1 appeared to be more resistant to LACV-mediated neuronal damage than wild-type mice, despite having similar viral loads in their brain [192]. Nonetheless, an earlier study demonstrated a neuroprotective role for SARM-1 against lethal WNV infection [193]. Finally, neuronal apoptosis can be induced by increased expression of apoptotic-related genes, that is, TNF $\alpha$, FasL, and TRAIL, which have been shown following infection with some encephalitic arboviruses such as TBEV and VEEV $[186,194]$. In VEEV-infected mice, neuronal apoptosis was observed in areas of the brain that contained astrogliosis and inflammation in the absence of viral antigens [185, 186]. Similarly, apoptosis of uninfected neurons was identified in a primate model of JEV infection [154], indicating an alternate, indirect mechanism of neuronal death. A better understanding of molecular elements involved in arboviral-mediated neuronal apoptosis will provide insights into mechanisms of neurodegeneration and will aid in development of antiviral therapies.

While inflammatory responses within the CNS play an important role in both control and clearance of viral infection, uncontrolled responses can be neuropathogenic. Indeed, neuropathogenesis of arboviruses has been often associated with neuroinflammation, which can cause neuronal death and disruption of the BBB. Following CNS infection by arboviruses, both infected target cells and bystander cells release an array of chemokines and proinflammatory cytokines, which trigger neuroinflammation. Neurons release several inflammatory cytokines, such as interleukin (IL)- $1 \beta$, tumor necrosis factor (TNF)- $\alpha$, and IL-6 in response to infection by encephalitic flaviviruses, such as WNV and JEV [195]. As well as impairing BBB integrity [152], elevated levels of IL$1 \beta$ can induce cell cycle arrest and apoptosis in neural precursor cells (NPCs) [196]. TNF- $\alpha$ impairs glutamate uptake by astrocytes, leading to neuronal death due to excitotoxicity [197]. Consistent with this, it has been shown that increased expression of TNF- $\alpha$ after infection with WNV and JEV is correlated with neuronal death $[154,195]$, and that neutralizing antibodies specific for IL- $1 \beta$ and TNF- $\alpha$ protected neurons from WNV-induced cell death [195]. The release of inflammatory cytokines by neurons can trigger gliosis (i.e., microglial and astrocyte activation), which is one of the major hallmarks of arboviral neuropathogenesis [154, 186, 198].
Although glial cells are not generally as permissive to arboviral infection as neurons, they release many more inflammatory mediators, which is likely to perturb the balance between protective and pathogenic immune responses [199]. Activated astrocytes and microglia play an important role in inflammatory responses during natural infection with encephalitic flaviviruses, namely JEV [200], WNV [201], and TBEV [198], as well as encephalitic alphaviruses [186]. Upon activation, astrocytes and microglia release several chemokines and cytokines such as TNF- $\alpha$, IL- 6 , C-X-C motif chemokine ligand (CXCL)10, chemokine (C-C motif) ligand 2, monocyte chemoattractant protein-1, RANTES, IFN- $\gamma$-induced protein 10, and matrix metalloproteinases [154, 195, 202-204]. Elevated levels of matrix metalloproteinases disrupts BBB by degrading TJ proteins [203, 205], allowing unrestricted entry of leukocytes into the brain, which further exacerbates neuroinflammation. Activated microglia also release nitric oxide (NO) in response to infection with flaviviruses $[202,206]$. While NO clearly has antiviral activities, a high level of NO is toxic to neurons, and its antiviral effects can also be virus specific [206]. Consistently, high levels of NO was correlated with accelerated death in mice infected with VEEV [186], and its inhibition prolonged survival time in TBEV-, MVEV-, and VEEV-infected mice [204, 206, 207]. Alternatively, inflammatory responses can result in formation of reactive oxygen species, which, in turn, triggers neuronal death. Notably, attenuated strains of VEEV and TBEV induced delayed or no cytokine response in the CNS, despite displaying similar tissue tropism or replication kinetics [186, 208]. A recent study also showed that it is not virus itself but the inflammatory responses that cause BBB disruption following JEV infection of mice [151]. Thus, the extent of host immune responses is positively linked to neuropathogenesis of some encephalitic arboviruses.

\section{Innate Immune Response to Arboviruses in the CNS}

As in peripheral organs, the innate intracellular responses are the first line of defense against invading pathogens in the CNS. These rapid antiviral responses are particularly important in controlling viral replication and thus preventing irreversible loss of neurons. Type I IFN signaling is a key component of these responses, and it is triggered by recognition of arboviral pathogen-associated molecular patterns via PRRs (i.e., TLRs, NOD-like receptors, and RLRs), which are expressed by neurons and glial cells in the CNS [209]. RIGI and MDA5 appeared to be involved in the induction of type I IFN against WNV, such that disruption of these pathways abolished activation of the antiviral response to WNV [191]. In addition, mice deficient in MAVS showed increased inflammation in CNS with no protection against WNV [114]. Similarly, lack of MAVS in primary cortical neurons was 
associated with enhanced virus production after infection with WNV. These cells were also less efficient at expressing IFN- $\beta$ and ISGs relative to wild-type cells [114]. Thus, RLR signaling appears to play a regulatory role in modulating innate immune responses in the CNS against flaviviruses. RIG-Imediated induction of type I IFNs has also been shown following infection with other encephalitic arboviruses, such as LACV and JEV [210, 211].

The role of TLR signaling in induction of protective immune responses against arboviral infections remains controversial. TLR3-deficient mice displayed increased viral load in the brain following intracranial challenge with WNV [116]. Likewise, lack of TLR3 in mice infected with JEV was associated with higher frequency of inflammatory monocytes in the CNS, enhanced number of activated microglia, and elevated levels of IL- 6 and TNF- $\alpha$ in the CNS, along with increased BBB permeability [212]. However, ablation of TLR3 did not alter virus titers in the CNS after intracranial inoculation of mice with JEV [212]. Conversely, in another study there was no significant difference in survival between wild-type and TLR3-deficient mice after intracranial infection with WNV [117]. Additionally, TLR3 was suggested to be a risk factor for severity of TBEV infections [213]. Further studies using other encephalitic arboviruses are therefore needed to better clarify the role of TLR3 responses in the CNS against invading neurotropic viruses.

Brain-specific TLR7 knockdown (TLR7 ${ }^{\mathrm{KD}}$ ) mice showed no significant differences in susceptibility to JEV compared with wild-type mice when subcutaneously infected with virus [214]. However, TLR $7^{\mathrm{KD}}$ mice demonstrated reduced levels of IFN- $\alpha$ mRNA accompanied by increased viral loads and proinflammatory cytokines in their brain. In addition, they had reduced levels of two additional antiviral proteins-IFN-induced antiviral RNA-binding protein 1 and OAS-like 1 (OAS1) - in their brain tissues. Similarly, TLR7-deficient mice displayed higher viral loads in the CNS than wild-type mice after intracranial inoculation with another flavivirus, Langat virus. However, the absence of TLR7 did not significantly alter the incidence or onset of clinical symptoms [215]. TLRs are also involved in recognition of alphaviruses in the brain. In this regard, increased expression of multiple TLRs, namely TLR1, TLR2, TLR3, TLR7, and TLR9, and their downstream signaling genes (i.e. $N f k b$ and $I r f$ ) were observed in brain tissues of VEEV-infected mice [216].

Both neurons and glial cells release type I IFNs in response to arboviral infections $[217,218]$. As well as playing a critical role in controlling viral spread, tropism, and pathogenesis, IFNs are essential for the formation of TJs [152]. Mice deficient in IFN- $\alpha / \beta \mathrm{R}, \mathrm{PKR}$, or RNAase L (antiviral proteins that are induced by IFN) displayed increased viral loads in CNS and accelerated death after intracranial infection with WNV $[110,121]$. Likewise, pretreatment with IFN- $\alpha$, IFN- $\beta$, or IFN- $\gamma$ also renders cortical neurons resistance to $\mathrm{WNV}$ infection [110]. The residential glial cells in the brain are activated in response to IFN- $\gamma$, and express a variety of PRRs that are involved in recognition of apoptotic-associated molecular patterns on the surface of apoptotic cells. Although IFN- $\gamma$ participated in the clearance of Sindbis virus, a mosquito-borne alphavirus, from infected neurons [219], it was dispensable for clearance of WNV from CNS [137]. Collectively, these observations suggest that type I IFN signaling directly modulates viral replication in CNS tissues, and that IFN- $\gamma$ is indirectly involved in clearance of apoptotic cells from the CNS.

\section{Viral Clearance from the CNS}

PRR signaling leads to the induction of adaptive immune responses, which are required for clearance of viral infections in the CNS [220-222]. Increased permeability of the BBB following arboviral infection allows entry of $\mathrm{B}$ cells and neutralizing Abs (nAbs) into the CNS. Once in the CNS, nAbs bind cell-free viruses, preventing new viral infections. Mice deficient for B cells and antibody production demonstrated higher viral loads in CNS and increased vulnerability to lethal WNV infection than wild-type mice [221]. Similarly, adoptive transfer of monoclonal antibodies protected mice from lethal encephalitis caused by other flaviviruses, namely JEV [223], SLEV [224], and yellow fever virus [225]. Further, high levels of JEV-specific IgM and IgG in the CSF was linked to virus clearance from the CNS and a better clinical outcome in patients [226, 227]. Development of nAbs was also associated with longer survival after intracerebral inoculation of mice with TBEV [208].

Antibody-mediated virus clearance from infected neurons have also been described for alphaviruses and RVFV [228-230]. Nonetheless, antibody response appeared to be dispensable for clearance of VEEV from CNS [231]. In addition, antibody response was not required for recovery of $\mu \mathrm{MT}$ mice from encephalomyelitis induced by attenuated strains of VEEV [232], such that these mice were able to reduce dramatically virus titers in the CNS and clear virus from CSF, in the absence of antiviral antibody.

Elimination of virus-infected cells in the CNS requires a CD8 T-cell response [233-236]. In response to WNV and JEV infections, neurons release CXCL10, which is required for recruitment of CD8 T cells into the brain via the $\mathrm{C}-\mathrm{X}-\mathrm{C}$ chemokine receptor (CXCR)3 [151, 170]. Mice lacking CXCL10 displayed high viral loads in the CNS, and increased mortality after WNV infection [170]. Interestingly, CXCL10 appeared to be important for clearance of WNV from CNS but not from peripheral lymphoid tissues [170]. Unlike CXCL10, CXCL12 is constitutively expressed on basolateral surfaces of CNS endothelial and retains CD8 T cells in perivascular space via CXCR4 and inhibits their entry into CNS. Hence, inhibition of 
CXCR4 results in enhanced entry of CD8 T cells into the CNS and improves mice survival from lethal WNV infection [233]. Further, mice deficient in CD8 T cells, major histocompatibility complex I, or perforin were unable to clear WNV infection from CNS, had increased viral burden in the CNS, and displayed higher mortality rate after infection with WNV than wild-type mice [137, 236].

CD8 T-cell responses are also important for clearance of other encephalitic arboviruses from the CNS. For instance, intracranial, but not peripheral transfer, of anti-JEV effector cells protected mice from lethal intracranial challenge with JEV [237, 238]. Nonetheless, CD8 T cells contribute to both recovery and immunopathology of WNV infection [239], and the presence of regulatory T cells in the CNS of mice infected with WNV is associated with reduced immunopathology both in humans and mice [240]. In addition, the CD8 T-cell response was not required for clearance of RVFV from the CNS [229], or for protection against lethal VEEV encephalitis [231]. Furthermore, analysis of paraffin-embedded autoptic brain tissue of human TBEV cases suggest that CD8 T cells can cause significant neuronal degeneration via induction of bystander damage [241], and lack of CD8 T cells was correlated with increased survival time in mice infected with TBEV [242]. Thus, CD8 T-cell response can be beneficial, deleterious, or both, depending on the virus.

CD4 T cells can also clear virus from infected neurons via a noncytolytic pathway, which involve production of IFN- $\gamma$. Adoptive transfer of CD4 $\mathrm{T}$ cells into RAG knockout mice resulted in virus clearance from the CNS and conferred resistance to lethal WNV infections in the absence of any B cells or CD8 T-cell responses [243]. In addition, mice deficient in CD4 displayed prolonged WNV infection in the CNS, and eventually died 50 days postinfection. Importantly, CD4deficient mice showed unaltered viral loads in the spleen, indicating that CD4 $\mathrm{T}$ cells are required for limiting WNV infection in the CNS but not in the periphery [222]. CD4 T cells are also required for protection against infection with other arboviruses, including JEV [237], yellow fever virus [244], TBEV [242], RVFV [229], and VEEV [231]. CD4 Tcell response resulted in a dramatic reduction of virus titers in the CNS and mediated full recovery of $\mu \mathrm{MT}$ mice from VEEV-induced encephalomyelitis [232].

\section{Susceptibility Factors for Arboviral Encephalitis: Lessons from Murine Models}

The clinical manifestation of arboviral infections in both mice and humans varies greatly, depending on several host and virus related factors. The clinical outcomes are also influenced by the route of viral administration. For instance, dermal inoculation of $\mathrm{C} 3 \mathrm{H} / \mathrm{HeN}$ and $\mathrm{BALB} / \mathrm{C}$ mice with TC83, a highly attenuated strain of VEEV, is typically avirulent [50].
Nonetheless, aerosol inoculation of $\mathrm{C} 3 \mathrm{H} / \mathrm{HeN}$ mice with TC83 led to encephalitis and $100 \%$ lethality [245]. Age is another determining factor that affects the clinical presentation of arboviral infection. While immunocompetent individuals of all ages may present with neurologic symptoms after infection with WNV, the risk of severe disease increases in elderly, as well as immunocompromised, hosts. Lethal infections of WNV are more prevalent in older individuals [246], despite a fairly uniform incidence rate among different age groups [247]. The age-related increased vulnerability to WNV in a mouse model was correlated to defects in CD4 and CD8 T-cell responses [248]. CD8 T cells from old mice were severely inefficient in producing IFN- $\gamma, \mathrm{TNF}-\alpha$, and granzyme B. In line with this, passive transfer of IFN- $\gamma$ or perforin-deficient $\mathrm{T}$ cells into RAG knockout mice did not confer any noticeable anti-WNV protection [248]. Dysregulation of TLR3 and TLR7 responses in the elderly has also been associated with enhanced vulnerability to lethal WNV infections [249, 250].

In contrast to WNV, JEV demonstrates particular tropism for developing neurons and NPCs [251]. Hence, children are at high risk of developing neurologic problems after JEV infection. Although JEV infection does not affect viability of NPCs, it severely impairs their proliferation ability [251]. Likewise, severity of LACV infections reduces with increasing age, both in humans and mice [119, 252]. Weanling mice displayed reduced type I IFNs responses, which was associated with high viral loads in the brain and severe neurologic disease. In contrast, strong production of type I IFN in adults limited virus dissemination to the $\mathrm{CNS}$ and provided protection against lethal LACV. Notably, differences in myeloid DC responses between weanling and adult mice were accounted for vulnerability to LACV-induced neurologic disease [119]. Similarly, maturation of neurons in vitro restricted replication of several arboviruses, including Sindbis virus, VEEV, WEEV, and LACV [253, 254], and delayed virus-induced translational arrest [254], which allows a longer period for production of antiviral proteins by the host. Indeed, early restriction of virus replication in the periphery contributed to age-dependent resistance to alphaviruses [255].

Type I IFN responses also appear to be important for placental infection with ZIKV. In a recent publication, two murine models of placental and fetal disease associated with in utero transmission of ZIKV were established via use of genetic deletion or antibody neutralization of IFN- $\alpha /$ IFN- $\beta$ receptor [256]. These models may facilitate the study of the teratogenicity of ZIKV and allow testing of therapies and vaccines to prevent congenital malformations.

The incidence and severity of arboviral infection is also influenced by genetic variations in the host. Results from previous cohort studies revealed a direct correlation between CCR5 $\Delta 32$ homozygosity and symptomatic disease during infections with WNV and TBEV [257, 258]. However, the results from recent follow-up studies using larger cohorts 
failed to show any association between CCR5 deficiency and symptomatic infection with WNV or TBEV [259]. These discrepancies may be explained by differences in study design, cohort size, and the control populations used in these studies. Infection of mice with WNV led to an increase in the expression of CCR5 and its ligand, which was associated with enhanced migration of leukocytes into the brain and protection of mice against lethal infection [260]. Strong correlation between WNV infection and single nucleotide polymorphisms in IRF3, myxovirus resistance protein 1 and OAS1 was also observed by other studies [259, 261]. Similarly, genetic variations within the human OAS1 gene was found to modulate the outcome of infections with TBEV [262], and individuals with major histocompatibility complex B49 on CD8 T cells appeared to be more vulnerable to lethal LACV infections [263]. Elucidating the host genetic factors contributing to arboviral pathogenicity is imperative for identification of individuals that are at high risk of severe arboviral-induced disease, and providing potential therapeutic targets.

\section{Treatment and Prevention of Arbovirus Neurologic Infections}

There are currently no approved antiviral medications for the treatment of neurologic infections with arboviruses. Symptomatic relief may be provided with the use of antipyretics, fluid reconstitution in cases of severe emesis, or use of life support to maintain respiratory and circulatory systems as the infection is cleared or in the event of organ failure. In the following sections, we highlight treatments currently under investigation for encephalitis due to JEV, WNV, and LACV, and licensed and investigational vaccines used to prevent arbovirus infections.

\section{JEV}

Several investigators have highlighted the role of oxidative stress in neuronal apoptosis during JEV infection of the CNS. Consequently, several antioxidants have been studied to evaluate therapeutic efficacy during CNS infection with JEV. Minocycline, a semisynthetic derivative of tetracycline, was shown to protect mice from challenge with JEV when treatment is initiated within $24 \mathrm{~h}$ of infection [264]. The mechanism of action of minocycline was shown in a variety of studies to involve inhibition of oxidative stress with reduction of reactive oxygen species $[265,266]$. In a recent randomized controlled clinical trial, trends towards better outcomes were observed when minocycline was administered to individuals over the age of 12 years [267]. However, larger studies are needed to determine the true clinical efficacy of minocycline for JEV encephalitis. Similarly, arctigenin, a lignin derived from the greater burdock (Arctium lappa), was shown to inhibit oxidative stress from microglial activation and protect mice from challenge with JEV [268]. However, this agent has not been evaluated in clinical trial. Additional antioxidants have been evaluated for effects on JEV-mediated cell injury in vitro. These include the peroxisome proliferator-activated receptor- $\alpha$ agonist fenofibrate [269], and curcumin, a naturally occurring phenolic compound extracted from the rhizome of Curcuma longa L. [270]. However, these have not yet been tested in animal models.

There are two JEV vaccines that are licensed in the USA. An inactivated mouse brain-derived JE vaccine (JE-VAX; The Research Foundation for Microbial Diseases of Osaka University, Osaka, Japan), was originally licensed in 1992 to prevent JE in persons aged $\geq 1$ year that are traveling to JEVendemic countries [271]. However, as production of this vaccine has ceased, supplies are limited. In March 2009, an inactivated Vero cell culture-derived vaccine (IXIARO; Valneva Austria GmbH, Wien, Austria) was licensed for use in persons aged $\geq 17$ years $[272,273]$. Mouse brain-derived JE vaccine is now the only $\mathrm{JE}$ vaccine available for use in children aged $1-16$ years and is being reserved for this age group. Other JEV vaccines, including live-attenuated SA14-14-2 JEV vaccine, are manufactured and used in Asia but are not licensed for use in the USA [274].

\section{WNV}

The critical role of type I IFN in virologic control during WNV infection has led to the use of IFN- $\alpha$ in human WNV infections, with varying results $[152,275]$. In 1 report, 2 middle-aged patients with encephalitis exhibited marked improvement in CNS function after 2 doses, and had limited neurologic sequelae with almost complete recovery [276]. However, despite treatement with IFN- $\alpha$, an elderly patient with WNV encephalitis and flaccid paralysis died [277]. Clinical trials are needed to better evaluate the efficacy of IFN- $\alpha$ in patients of varying ages with WNV encephalitis.

While there are 4 US Department of Agriculture-approved, licensed vaccines to prevent illness due to WNV infection for horses, there are no licensed vaccines for prevention of disease in humans. However, there is currently an ongoing National Institutes of Health-sponsored clinical trial using WNV inactivated with HydroVax-001, a novel, hydrogen peroxidebased process that inactivates virus while preserving immunoreactive surface structures [278].

\section{LACV}

Early studies examining antiviral agents demonstrated that ribavirin inhibits the transcription of the LACV genome in host cells [279]. Several case reports of its use in the setting of severe LACV encephalitis suggested it may improve outcome [280, 281]. In phase I, IIA, and IIB clinical trials, 
however, higher doses were needed to achieve appropriate CSF levels of ribavirin, which led to adverse events that necessitated trial discontinuation [282]. There are currently no licensed or investigational vaccines for LACV.

\section{VEEV, EEEV, and WEEV}

Treatment of encephalitis due to VEEV, EEEV, or WEEV is mostly supportive as there are no antiviral treatments for these viruses. A live-attenuated VEEV vaccine (TC-83) is licensed for protection of horses in endemic areas. The TC-83 strain was generated via passage of strain Tr-D 83 times in heart cells of a guinea pig; C-84 is a derivative of TC-83 [283]. It is highly reactogenic, causing illness in up to $20 \%$ of recipients, but poorly immunogenic. Military personnel require boosters with investigational formalin-inactivated VEEV [284]. EEEV and WEEV formalin-inactivated vaccines are available, but are poorly immunogenic with unknown ability to protect against variant viruses [283,285]. There are no prophylactic or therapeutic drugs to prevent or treat, respectively, VEEV, EEEV, or WEEV encephalitis.

Acknowledgments Funding for was provided by the National Institutes of Health (R01 NS052632, U19 AI083019, and P01 NS059560) and by Defense Threat Reduction Agency (HDTRA 1-151-0032).

Required Author Forms Disclosure forms provided by the authors are available with the online version of this article.

\section{References}

1. Weaver SC, Winegar R, Manger ID, Forrester NL. Alphaviruses: Population genetics and determinants of emergence. Antiviral Res 2012;94:242-257.

2. Powers AM, Brault AC, Shirako Y, et al. Evolutionary relationships and systematics of the alphaviruses. J Virol 2001;75:1011810131.

3. Rust RS, Thompson WH, Matthews CG, Beaty BJ, Chun RW. La Crosse and other forms of California encephalitis. J Child Neurol 1999;14:1-14.

4. Go YY, Balasuriya UBR, Lee C-K. Zoonotic encephalitides caused by arboviruses: transmission and epidemiology of alphaviruses and flaviviruses. Clin Exp Vaccine Res 2014;3:5877.

5. Deresiewicz RL, Thaler SJ, Hsu L, Zamani AA. Clinical and neuroradiographic manifestations of eastern equine encephalitis. N Engl J Med 1997;336:1867-1874.

6. Froeschle JE, Reeves WC. Serologic epidemiology of western equine and st. louis encephalitis virus infection in california. ii. analysis of inapparent infections in residents of an endemic area. Am J Epidemiol 1965;81:44-51.

7. Atkins GJ, Atkins GJ. The pathogenesis of alphaviruses, the pathogenesis of alphaviruses. Int Sch Res Not Int Sch Res Not 2012;2013:e861912.

8. Weaver SC, Ferro C, Barrera R, Boshell J, Navarro J-C. Venezuelan equine encephalitis. Annu Rev Entomol 2004;49: $141-174$
9. Centers for Disease Control and Prevention (CDC). Eastern equine encephalitis-New Hampshire and Massachusetts, August-September 2005. MMWR 2006;55:697-700.

10. Adams AP, Navarro-Lopez R, Ramirez-Aguilar FJ, et al. Venezuelan equine encephalitis virus activity in the Gulf Coast region of Mexico, 2003-2010. PLoS Negl Trop Dis 2012;6: e1875.

11. Lemant J, Boisson V, Winer A, et al. Serious acute chikungunya virus infection requiring intensive care during the Reunion Island outbreak in 2005-2006. Crit Care Med 2008:36:2536-2541.

12. Gérardin P, Barau G, Michault A, et al. Multidisciplinary prospective study of mother-to-child chikungunya virus infections on the island of La Réunion. PLoS Med 2008;5:e60.

13. Ganesan K, Diwan A, Shankar SK, Desai SB, Sainani GS, Katrak SM. Chikungunya encephalomyeloradiculitis: report of 2 cases with neuroimaging and 1 case with autopsy findings. AJNR Am J Neuroradiol 2008;29:1636-1637.

14. Lebrun $\mathrm{G}$, Chadda K, Reboux A-H, Martinet $\mathrm{O}$, Gaüzère B-A. Guillain-Barré syndrome after chikungunya infection. Emerg Infect Dis 2009;15:495-496.

15. Gérardin P, Couderc T, Bintner M, et al. Chikungunya virusassociated encephalitis: A cohort study on La Réunion Island, 2005-2009. Neurology 2016;86:94-102.

16. Lindsey NP, Lehman JA, Staples JE, Fischer M. West Nile virus and other nationally notifiable arboviral diseases - United States, 2014. MMWR Morb Mortal Wkly Rep 2015;64:929-934.

17. Selvey LA, Dailey L, Lindsay M, et al. The changing epidemiology of Murray Valley encephalitis in Australia: the 2011 outbreak and a review of the literature. PLoS Negl Trop Dis 2014;8:e2656.

18. Campbell GL, Hills SL, Fischer M, et al. Estimated global incidence of Japanese encephalitis: a systematic review. Bull World Health Organ 2011;89:766-774, 774A-774E.

19. Centers for Disease Control and Prevention (CDC). Intrauterine West Nile virus infection-New York, 2002. MMWR 2002;51: 1135-1136.

20. Alpert SG, Fergerson J, Noël LP. Intrauterine West Nile virus: ocular and systemic findings. Am J Ophthalmol 2003;136:733735.

21. Solomon T, Dung NM, Vaughn DW, et al. Neurological manifestations of dengue infection. Lancet Lond Engl 2000;355:10531059 .

22. Hayes EB. Zika virus outside Africa. Emerg Infect Dis 2009;15: 1347-1350.

23. Lazear HM, Govero J, Smith AM, et al. A mouse model of Zika virus pathogenesis. Cell Host Microbe 2016;19:720-730.

24. Carteaux G, Maquart M, Bedet A, et al. Zika Virus Associated with Meningoencephalitis. N Engl J Med 2016;374:1595-1596.

25. Oehler E, Watrin L, Larre P, et al. Zika virus infection complicated by Guillain-Barre syndrome - case report, French Polynesia, December 2013. Euro Surveill 2014; 19:20720.

26. Wong P-SJ, Li MI, Chong C-S, Ng L-C, Tan C-H. Aedes (Stegomyia) albopictus (Skuse): a potential vector of Zika virus in Singapore. PLoS Negl Trop Dis 2013;7:e2348.

27. Brasil P, Pereira JP, Raja Gabaglia C, et al. Zika virus infection in pregnant women in Rio de Janeiro - preliminary report. N Engl J Med 2016 Mar 4 [Epub ahead of print].

28. Carod-Artal FJ. Epidemiology and neurological complications of infection by the Zika virus: a new emerging neurotropic virus. Rev Neurol 2016;62:317-328.

29. Centers for Disease Control and Prevention (CDC). Zika virus disease in the United States, 2015-2016. Available at: http:// www.cdc.gov/zika/geo/united-states.html. Accessed 15 May 2016.

30. Foy BD, Kobylinski KC, Chilson Foy JL, et al. Probable nonvector-borne transmission of Zika virus, Colorado, USA. Emerg Infect Dis 2011;17:880-882. 
31. McCarthy M. Zika virus was transmitted by sexual contact in Texas, health officials report. BMJ 2016;352:i720.

32. Musso D, Roche C, Robin E, Nhan T, Teissier A, Cao-Lormeau VM. Potential sexual transmission of Zika virus. Emerg Infect Dis 2015;21:359-361.

33. Atkinson B, Hearn P, Afrough B, et al. Detection of Zika virus in semen. Emerg Infect Dis 2016;22:940.

34. Soldan SS, González-Scarano F. Emerging infectious diseases: the Bunyaviridae. J Neurovirol 2005;11:412-423.

35. Rolin AI, Berrang-Ford L, Kulkarni MA. The risk of Rift Valley fever virus introduction and establishment in the United States and European Union. Emerg Microbes Infect 2013;2:e81.

36. El-Akkad AM. Rift Valley fever outbreak in Egypt. OctoberDecember 1977. J Egypt Public Health Assoc 1978;53:123-128.

37. Ikegami T, Makino S. The pathogenesis of Rift Valley fever. Viruses 2011;3:493-519.

38. Cusi MG, Savellini GG, Zanelli G. Toscana virus epidemiology: from Italy to beyond. Open Virol J 2010;4:22-28.

39. Dincer E, Gargari S, Ozkul A, Ergunay K. Potential animal reservoirs of Toscana virus and coinfections with Leishmania infantum in Turkey. Am J Trop Med Hyg 2015;92:690-697.

40. Bowen GS, McLean RG, Shriner RB, et al. The ecology of Colorado tick fever in Rocky Mountain National Park in 1974. II. Infection in small mammals. Am J Trop Med Hyg 1981;30: 490-496.

41. McLean RG, Carey AB, Kirk LJ, Francy DB. Ecology of porcupines (Erethizon dorsatum) and Colorado tick fever virus in Rocky Mountain National Park, 1975-1977. J Med Entomol 1993;30:236-238.

42. Klasco R. Colorado tick fever. Med Clin North Am 2002;86:435440 , ix.

43. Yendell SJ, Fischer M, Staples JE. Colorado tick fever in the United States, 2002-2012. Vector Borne Zoonotic Dis 2015;15: 311-316.

44. Pedrosa PBS, Cardoso TAO. Viral infections in workers in hospital and research laboratory settings: a comparative review of infection modes and respective biosafety aspects. Int $\mathrm{J}$ Infect Dis 2011;15:e366-e376.

45. Taylor KG, Paessler S. Pathogenesis of Venezuelan equine encephalitis. Vet Microbiol 2013;167:145-150.

46. Centers for Disease Control and Prevention (CDC). Venezuelan equine encephalitis - Colombia, 1995. MMWR Morb Mortal Wkly Rep 1995;44:721-724.

47. Johnson KM, Shelokov A, Peralta PH, Dammin GJ, Young NA. Recovery of Venezuelan equine encephalomyelitis virus in Panama. A fatal case in man. Am J Trop Med Hyg 1968;17: 432-440.

48. Hatanpaa KJ, Kim JH. Neuropathology of viral infections. Handb Clin Neurol 2014;123:193-214.

49. Miller LD, Pearson JE, Muhm RL. A comparison of clinical manifestations and pathology of the equine encephalidites: VEE, WEE, EEE. Proc Annu Meet U S Anim Health Assoc 1973;(77):629-31.

50. Steele KE, Twenhafel NA. REVIEW PAPER: pathology of animal models of alphavirus encephalitis. Vet Pathol 2010;47:790805 .

51. Hanson RP, Sulkin SE, Beuscher EL, Hammon WM, McKinney RW, Work TH. Arbovirus infections of laboratory workers. Extent of problem emphasizes the need for more effective measures to reduce hazards. Science 1967;158:1283-1286.

52. Sourisseau M, Schilte C, Casartelli N, et al. Characterization of reemerging chikungunya virus. PLoS Pathog 2007;3:e89.

53. Schilte C, Staikowsky F, Staikovsky F, et al. Chikungunya virusassociated long-term arthralgia: a 36-month prospective longitudinal study. PLoS Negl Trop Dis 2013;7:e2137.
54. Lenglet Y, Barau G, Robillard P-Y, et al. [Chikungunya infection in pregnancy: Evidence for intrauterine infection in pregnant women and vertical transmission in the parturient. Survey of the Reunion Island outbreak]. J Gynécologie Obstétrique Biol Reprod 2006;35:578-583.

55. Solomon T. Flavivirus encephalitis. N Engl J Med 2004;351:370 378.

56. Vaughn DW, Hoke CH. The epidemiology of Japanese encephalitis: prospects for prevention. Epidemiol Rev 1992;14:197-221.

57. Porterfield JS. Exotic viral infections. Chapman \& Hall Medical; 1995, pp. 175-181.

58. Rust RS. Human arboviral encephalitis. Semin Pediatr Neurol 2012;19:130-151.

59. Dutta K, Basu A. Japanese encephalitis: A tale of inflammation and degeneration in the central nervous system. In: Peterson PK, Toborek M, editors. Neuroinflammation and Neurodegeneration. Springer New York; 2014. pp. 309-335.

60. Iwamoto M, Jernigan DB, Guasch A, et al. Transmission of West Nile virus from an organ donor to four transplant recipients. N Engl J Med 2003;348:2196-2203.

61. Macedo de Oliveira A, Beecham BD, Montgomery SP, et al. West Nile virus blood transfusion-related infection despite nucleic acid testing. Transfusion 2004;44:1695-1699.

62. Hayes EB, Sejvar JJ, Zaki SR, Lanciotti RS, Bode AV, Campbell GL. Virology, pathology, and clinical manifestations of West Nile virus disease. Emerg Infect Dis 2005;11:1174-1179.

63. Centers for Disease Control and Prevention (CDC). Acute flaccid paralysis syndrome associated with West Nile virus infectionMississippi and Louisiana, July-August 2002. MMWR Morb Mortal Wkly Rep 2002;51:825-828.

64. Sejvar JJ, Haddad MB, Tierney BC, et al. Neurologic manifestations and outcome of West Nile virus infection. JAMA 2003;290: 511-515.

65. Wang H, Siddharthan V, Kesler KK, et al. Fatal neurological respiratory insufficiency is common among viral encephalitides. J Infect Dis 2013;208:573-583.

66. Oyer RJ, David Beckham J, Tyler KL. West Nile and St. Louis encephalitis viruses. Handb Clin Neurol 2014;123:433-447.

67. Fratkin JD, Leis AA, Stokic DS, Slavinski SA, Geiss RW. Spinal cord neuropathology in human West Nile virus infection. Arch Pathol Lab Med 2004;128:533-537.

68. Varatharaj A. Encephalitis in the clinical spectrum of dengue infection. Neurol India 2010;58:585-591.

69. Verma R, Sharma P, Garg RK, Atam V, Singh MK, Mehrotra HS Neurological complications of dengue fever: Experience from a tertiary center of north India. Ann Indian Acad Neurol 2011;14: 272-278.

70. Madi D, Achappa B, Ramapuram JT, Chowta N, Laxman M, Mahalingam S. Dengue encephalitis-A rare manifestation of dengue fever. Asian Pac J Trop Biomed 2014;4(Suppl, 1):S70-S72.

71. Christo PP. Encephalitis by dengue virus and other arboviruses. Arq Neuropsiquiatr 2015;73:641-643.

72. Dick GWA, Kitchen SF, Haddow AJ. Zika virus. I. Isolations and serological specificity. Trans R Soc Trop Med Hyg 1952;46:509_ 520.

73. Duffy MR, Chen T-H, Hancock WT, et al. Zika virus outbreak on Yap Island, Federated States of Micronesia. N Engl J Med 2009;360:2536-2543.

74. Sarno M, Sacramento GA, Khouri R, et al. Zika virus infection and stillbirths: A case of hydrops fetalis, hydranencephaly and fetal demise. PLoS Negl Trop Dis 2016;10:e0004517.

75. Ventura CV, Maia M, Ventura BV, et al. Ophthalmological findings in infants with microcephaly and presumable intra-uterus Zika virus infection. Arq Bras Oftalmol 2016;79:1-3. 
76. Ventura CV, Maia M, Bravo-Filho V, Góis AL, Belfort R. Zika virus in Brazil and macular atrophy in a child with microcephaly. Lancet 2016;387:228.

77. Oliveira Melo AS, Malinger G, Ximenes R, Szejnfeld PO, Alves Sampaio S, Bispo de Filippis AM. Zika virus intrauterine infection causes fetal brain abnormality and microcephaly: tip of the iceberg? Ultrasound Obstet Gynecol 2016;47:6-7.

78. Schuler-Faccini L, Ribeiro EM, Feitosa IML, et al. Possible association between Zika virus infection and microcephaly - Brazil, 2015. MMWR Morb Mortal Wkly Rep 2016;65:59-62.

79. Wiley CA, Bhardwaj N, Ross TM, Bissel SJ. Emerging infections of CNS: Avian influenza A virus, Rift Valley fever virus and human parechovirus. Brain Pathol 2015;25:634-650.

80. Bartels S, de Boni L, Kretzschmar HA, Heckmann JG. Lethal encephalitis caused by the Toscana virus in an elderly patient. $\mathrm{J}$ Neurol 2012;259:175-177.

81. Leiby DA, Gill JE. Transfusion-transmitted tick-borne infections: a cornucopia of threats. Transfus Med Rev 2004;18:293-306.

82. Goodpasture HC, Poland JD, Francy DB, Bowen GS, Horn KA. Colorado tick fever: clinical, epidemiologic, and laboratory aspects of 228 cases in Colorado in 1973-1974. Ann Intern Med 1978;88:303-310.

83. Berg PJ, Smallfield S, Svien L. An investigation of depression and fatigue post West Nile virus infection. S D Med 2010;63:127-129, 131-133.

84. Hoffman JE, Paschal KA. Functional outcomes of adult patients with West Nile virus admitted to a rehabilitation hospital. J Geriatr Phys Ther 2013;36:55-62.

85. Berner YN, Lang R, Chowers MY. Outcome of West Nile fever in older adults. J Am Geriatr Soc 2002;50:1844-1846.

86. Arciniegas DB, Anderson CA. Viral encephalitis: neuropsychiatric and neurobehavioral aspects. Curr Psychiatry Rep 2004;6:372379.

87. Klee AL, Maidin B, Edwin B, et al. Long-term prognosis for clinical West Nile virus infection. Emerg Infect Dis 2004;10: 1405-1411.

88. Carson PJ, Konewko P, Wold KS, et al. Long-term clinical and neuropsychological outcomes of West Nile virus infection. Clin Infect Dis 2006;43:723-730.

89. Haaland KY, Sadek J, Pergam S, et al. Mental status after West Nile virus infection. Emerg Infect Dis 2006;12:1260-1262.

90. Davis LE, DeBiasi R, Goade DE, et al. West Nile virus neuroinvasive disease. Ann Neurol 2006;60:286-300.

91. Sejvar JJ. The long-term outcomes of human West Nile virus infection. Clin Infect Dis 2007;44:1617-1624.

92. Sadek JR, Pergam SA, Harrington JA, et al. Persistent neuropsychological impairment associated with West Nile virus infection. J Clin Exp Neuropsychol 2010;32:81-87.

93. Sejvar JJ, Curns AT, Welburg L, et al. Neurocognitive and functional outcomes in persons recovering from West Nile virus illness. J Neuropsychol 2008;2:477-499.

94. Cvejic E, Lemon J, Hickie IB, Lloyd AR, Vollmer-Conna U. Neurocognitive disturbances associated with acute infectious mononucleosis, Ross River fever and Q fever: A preliminary investigation of inflammatory and genetic correlates. Brain Behav Immun 2014;36:207-214.

95. Fitch WM, Artsob H. Powassan encephalitis in new brunswick. Can Fam Physician 1990;36:1289-1290.

96. Lessell S, Collins TE. Ophthalmoplegia in Powassan encephalitis. Neurology 2003;60:1726-1727.

97. Greve KW, Houston RJ, Adams D, et al. The neurobehavioural consequences of St. Louis encephalitis infection. Brain Inj 2002;16:917-927.

98. Monnet FP. Behavioural disturbances following Japanese B encephalitis. Eur Psychiatry 2003;18:269-273.
99. Labeaud AD, Bashir F, King CH. Measuring the burden of arboviral diseases: the spectrum of morbidity and mortality from four prevalent infections. Popul Health Metr 2011;9:1.

100. Joshi R, Mishra PK, Joshi D, et al. Clinical presentation, etiology, and survival in adult acute encephalitis syndrome in rural Central India. Clin Neurol Neurosurg 2013;115:1753-1761.

101. Styer LM, Kent KA, Albright RG, Bennett CJ, Kramer LD, Bernard KA. Mosquitoes inoculate high doses of West Nile virus as they probe and feed on live hosts. PLoS Pathog 2007;3:12621270.

102. Garcia-Tapia D, Hassett DE, Mitchell WJ, Johnson GC, Kleiboeker SB. West Nile virus encephalitis: sequential histopathological and immunological events in a murine model of infection. J Neurovirol 2007;13:130-138.

103. Johnston LJ, Halliday GM, King NJ. Langerhans cells migrate to local lymph nodes following cutaneous infection with an arbovirus. J Invest Dermatol 2000;114:560-568.

104. Lim P-Y, Behr MJ, Chadwick CM, Shi P-Y, Bernard KA. Keratinocytes are cell targets of West Nile virus in vivo. J Virol 2011;85:5197-5201.

105. MacDonald GH, Johnston RE. Role of dendritic cell targeting in Venezuelan equine encephalitis virus pathogenesis. J Virol 2000;74:914-922.

106. Gardner CL, Burke CW, Tesfay MZ, Glass PJ, Klimstra WB, Ryman KD. Eastern and Venezuelan equine encephalitis viruses differ in their ability to infect dendritic cells and macrophages: impact of altered cell tropism on pathogenesis. J Virol 2008;82: 10634-10646.

107. Vogel P, Kell WM, Fritz DL, Parker MD, Schoepp RJ. Early events in the pathogenesis of eastern equine encephalitis virus in mice. Am J Pathol 2005;166:159-171.

108. Bai F, Kong K-F, Dai J, et al. A paradoxical role for neutrophils in the pathogenesis of West Nile virus. J Infect Dis 2010;202:1804 1812

109. Ben-Nathan D, Huitinga I, Lustig S, van Rooijen N, Kobiler D. West Nile virus neuroinvasion and encephalitis induced by macrophage depletion in mice. Arch Virol 1996;141:459-469.

110. Samuel MA, Whitby K, Keller BC, et al. PKR and RNase L contribute to protection against lethal West Nile Virus infection by controlling early viral spread in the periphery and replication in neurons. J Virol 2006;80:7009-7019.

111. Goto A, Hayasaka D, Yoshii K, Mizutani T, Kariwa H, Takashima I. A BHK-21 cell culture-adapted tick-borne encephalitis virus mutant is attenuated for neuroinvasiveness. Vaccine 2003;21: 4043-4051.

112. Errett JS, Suthar MS, McMillan A, Diamond MS, Gale M. The essential, nonredundant roles of RIG-I and MDA5 in detecting and controlling West Nile virus infection. J Virol 2013;87:1141611425 .

113. Akhrymuk I, Frolov I, Frolova EI. Both RIG-I and MDA5 detect alphavirus replication in concentration-dependent mode. Virology 2016;487:230-241.

114. Suthar MS, Ma DY, Thomas S, et al. IPS-1 is essential for the control of West Nile virus infection and immunity. PLoS Pathog 2010;6:e1000757.

115. Lazear HM, Pinto AK, Ramos HJ, et al. Pattern recognition receptor MDA5 modulates CD8+ T cell-dependent clearance of West Nile virus from the central nervous system. J Virol 2013;87: 11401-11415.

116. Daffis S, Samuel MA, Suthar MS, Gale M, Diamond MS. Tolllike receptor 3 has a protective role against West Nile virus infection. J Virol 2008;82:10349-10358.

117. Wang T, Town T, Alexopoulou L, Anderson JF, Fikrig E, Flavell RA. Toll-like receptor 3 mediates West Nile virus entry into the brain causing lethal encephalitis. Nat Med 2004;10:1366-1373. 
118. Town T, Bai F, Wang T, et al. Toll-like receptor 7 mitigates lethal West Nile encephalitis via interleukin 23-dependent immune cell infiltration and homing. Immunity 2009;30:242-253.

119. Taylor KG, Woods TA, Winkler CW, Carmody AB, Peterson KE. Age-dependent myeloid dendritic cell responses mediate resistance to La Crosse virus-induced neurological disease. J Virol 2014;88:11070-11079.

120. Pinto AK, Ramos HJ, Wu X, et al. Deficient IFN signaling by myeloid cells leads to MAVS-dependent virus-induced sepsis. PLoS Pathog 2014;10:e1004086.

121. Samuel MA, Diamond MS. Alpha/beta interferon protects against lethal West Nile virus infection by restricting cellular tropism and enhancing neuronal survival. J Virol 2005;79:13350-13361.

122. Grieder FB, Vogel SN. Role of interferon and interferon regulatory factors in early protection against Venezuelan equine encephalitis virus infection. Virology 1999;257:106-118.

123. Schoneboom BA, Lee JS, Grieder FB. Early expression of IFN-alpha/beta and iNOS in the brains of Venezuelan equine encephalitis virus-infected mice. J Interferon Cytokine Res 2000;2:205-215.

124. White LJ, Wang J-G, Davis NL, Johnston RE. Role of alpha/beta interferon in Venezuelan equine encephalitis virus pathogenesis: Effect of an attenuating mutation in the $5^{\prime}$ untranslated region. J Virol 2001;75:3706-3718.

125. Müller U, Steinhoff U, Reis LF, et al. Functional role of type I and type II interferons in antiviral defense. Science 1994;264:1918-1921

126. Schuh T, Schultz J, Moelling K, Pavlovic J. DNA-based vaccine against La Crosse virus: protective immune response mediated by neutralizing antibodies and CD4+ T cells. Hum Gene Ther 1999;10:1649-1658.

127. Morrey JD, Day CW, Julander JG, Blatt LM, Smee DF, Sidwell RW. Effect of interferon-alpha and interferon-inducers on West Nile virus in mouse and hamster animal models. Antivir Chem Chemother 2004;15:101-109.

128. Lukaszewski RA, Brooks TJ. Pegylated alpha interferon is an effective treatment for virulent venezuelan equine encephalitis virus and has profound effects on the host immune response to infection. J Virol 2000;74:5006-5015.

129. Gilfoy FD, Mason PW. West Nile virus-induced interferon production is mediated by the double-stranded RNA-dependent protein kinase PKR. J Virol 2007;81:11148-11158.

130. Atasheva S, Akhrymuk M, Frolova EI, Frolov I. New PARP gene with an anti-alphavirus function. J Virol 2012;86:8147-8160.

131. Atasheva S, Frolova EI, Frolov I. Interferon-stimulated poly(ADP-Ribose) polymerases are potent inhibitors of cellular translation and virus replication. J Virol 2014;88:2116-2130.

132. Mudhasani R, Tran JP, Retterer C, et al. IFITM-2 and IFITM-3 but not IFITM-1 restrict Rift Valley fever virus. J Virol 2013;87:8451-8464.

133. Engle MJ, Diamond MS. Antibody prophylaxis and therapy against West Nile virus infection in wild-type and immunodeficient mice. J Virol 2003;77:12941-12949.

134. Halevy M, Akov Y, Ben-Nathan D, Kobiler D, Lachmi B, Lustig S. Loss of active neuroinvasiveness in attenuated strains of West Nile virus: pathogenicity in immunocompetent and SCID mice. Arch Virol 1994;137:355-370.

135. Diamond MS, Sitati EM, Friend LD, Higgs S, Shrestha B, Engle M. A critical role for induced IgM in the protection against West Nile virus infection. J Exp Med 2003;198:1853-1862.

136. Charles PC, Trgovcich J, Davis NL, Johnston RE. Immunopathogenesis and immune modulation of Venezuelan equine encephalitis virus-induced disease in the mouse. Virology 2001;284:190-202.
137. Shrestha B, Wang T, Samuel MA, et al. Gamma interferon plays a crucial early antiviral role in protection against West Nile virus infection. J Virol 2006;80:5338-5348.

138. Wang T, Scully E, Yin Z, et al. IFN-gamma-producing gamma delta $\mathrm{T}$ cells help control murine West Nile virus infection. J Immunol 1950 2003;171:2524-2531.

139. Samuel MA, Wang H, Siddharthan V, Morrey JD, Diamond MS Axonal transport mediates West Nile virus entry into the central nervous system and induces acute flaccid paralysis. Proc Natl Acad Sci U S A 2007;104:17140-17145.

140. Wang H, Siddharthan V, Hall JO, Morrey JD. West Nile virus preferentially transports along motor neuron axons after sciatic nerve injection of hamsters. J Neurovirol 2009;15:293-299.

141. Hunsperger EA, Roehrig JT. Nocodazole delays viral entry into the brain following footpad inoculation with West Nile virus in mice. J Neurovirol 2009; 15:211-218.

142. Monath TP, Cropp CB, Harrison AK. Mode of entry of a neurotropic arbovirus into the central nervous system. Reinvestigation of an old controversy. Lab Investig J Tech Methods Pathol 1983;48:399-410.

143. McMinn PC, Dalgarno L, Weir RC. A comparison of the spread of Murray Valley encephalitis viruses of high or low neuroinvasiveness in the tissues of Swiss mice after peripheral inoculation. Virology 1996;220:414-r23.

144. Charles PC, Walters E, Margolis F, Johnston RE. Mechanism of neuroinvasion of Venezuelan equine encephalitis virus in the mouse. Virology 1995;208:662-671.

145. Honnold SP, Mossel EC, Bakken RR, et al. Eastern equine encephalitis virus in mice II: pathogenesis is dependent on route of exposure. Virol J 2015;12:154.

146. Bennett RS, Cress CM, Ward JM, Firestone C-Y, Murphy BR, Whitehead SS. La Crosse virus infectivity, pathogenesis, and immunogenicity in mice and monkeys. Virol J 2008;5:25.

147. Danes L, Kufner J, Hrusková J, Rychterová V. The role of the olfactory route on infection of the respiratory tract with Venezuelan equine encephalitis virus in normal and operated Macaca rhesus monkeys. I. Results of virological examination; II. Results of histological examination. Acta Virol 1973;17:50-56.

148. Reed DS, Lackemeyer MG, Garza NL, et al. Severe encephalitis in cynomolgus macaques exposed to aerosolized Eastern equine encephalitis virus. J Infect Dis 2007;196:441-450.

149. Cardoso FL, Brites D, Brito MA. Looking at the blood-brain barrier: molecular anatomy and possible investigation approaches. Brain Res Rev 2010;64:328-363.

150. Verma S, Lo Y, Chapagain M, et al. West Nile virus infection modulates human brain microvascular endothelial cells tight junction proteins and cell adhesion molecules: Transmigration across the in vitro blood-brain barrier. Virology 2009;385:425-433.

151. Li F, Wang Y, Yu L, et al. Viral infection of the central nervous system and neuroinflammation precede blood-brain barrier disruption during Japanese encephalitis virus infection. J Virol 2015;89: 5602-5614.

152. Daniels BP, Holman DW, Cruz-Orengo L, Jujjavarapu H, Durrant DM, Klein RS. Viral pathogen-associated molecular patterns regulate blood-brain barrier integrity via competing innate cytokine signals. mBio 2014;5:e1476-14.

153. Suen WW, Prow NA, Hall RA, Bielefeldt-Ohmann H. Mechanism of West Nile virus neuroinvasion: A critical appraisal. Viruses 2014;6:2796-2825.

154. Myint KSA, Kipar A, Jarman RG, et al. Neuropathogenesis of Japanese encephalitis in a primate model. PLoS Negl Trop Dis 2014;8:e2980.

155. Hasebe R, Suzuki T, Makino Y, et al. Transcellular transport of West Nile virus-like particles across human endothelial cells depends on residues 156 and 159 of envelope protein. BMC Microbiol 2010;10:165. 
156. Liou ML, Hsu CY. Japanese encephalitis virus is transported across the cerebral blood vessels by endocytosis in mouse brain. Cell Tissue Res 1998;293:389-394.

157. Lazear HM, Daniels BP, Pinto AK, et al. Interferon- $\lambda$ restricts West Nile virus neuroinvasion by tightening the blood-brain barrier. Sci Transl Med 2015;7:284ra59.

158. Roe K, Kumar M, Lum S, Orillo B, Nerurkar VR, Verma S. West Nile virus-induced disruption of the blood-brain barrier in mice is characterized by the degradation of the junctional complex proteins and increase in multiple matrix metalloproteinases. J Gen Virol 2012;93:1193-1203.

159. Morrey JD, Olsen AL, Siddharthan V, et al. Increased blood-brain barrier permeability is not a primary determinant for lethality of West Nile virus infection in rodents. J Gen Virol 2008;89:467473.

160. Růžek D, Salát J, Singh SK, Kopecký J. Breakdown of the bloodbrain barrier during tick-borne encephalitis in mice is not dependent on CD8+ T-cells. PloS One 2011;6:e20472.

161. Schäfer A, Brooke CB, Whitmore AC, Johnston RE. The role of the blood-brain barrier during Venezuelan equine encephalitis virus infection. J Virol 2011;85:10682-10690.

162. Schäfer A, Whitmore AC, Konopka JL, Johnston RE. Replicon particles of Venezuelan equine encephalitis virus as a reductionist murine model for encephalitis. J Virol 2009;83:4275-4286.

163. Sharma A, Bhomia M, Honnold SP, Maheshwari RK. Role of adhesion molecules and inflammation in Venezuelan equine encephalitis virus infected mouse brain. Virol J 2011;8:197.

164. Roe K, Orillo B, Verma S. West Nile virus-induced cell adhesion molecules on human brain microvascular endothelial cells regulate leukocyte adhesion and modulate permeability of the in vitro blood-brain barrier model. PLoS ONE 2014;9:e102598.

165. King NJ, Shrestha B, Kesson AM. Immune modulation by flaviviruses. Adv Virus Res 2003;60:121-155.

166. Dai J, Wang P, Bai F, Town T, Fikrig E. ICAM-1 participates in the entry of West Nile virus into the central nervous system. J Virol 2008;82:4164-4168.

167. Myint KS, Raengsakulrach B, Young GD, et al. Production of lethal infection that resembles fatal human disease by intranasal inoculation of macaques with Japanese encephalitis virus. Am J Trop Med Hyg 1999;60:338-342.

168. Hase T, Dubois DR, Summers PL. Comparative study of mouse brains infected with Japanese encephalitis virus by intracerebral or intraperitoneal inoculation. Int J Exp Pathol 1990;71:857-869.

169. Matthews V, Robertson T, Kendrick T, Abdo M, Papadimitriou J, Mcminn P. Morphological features of Murray Valley encephalitis virus infection in the central nervous system of swiss mice. Int $\mathbf{J}$ Exp Pathol 2000;81:31-40.

170. Klein RS, Lin E, Zhang B, et al. Neuronal CXCL10 directs CD8+ T-cell recruitment and control of West Nile virus encephalitis. J Virol 2005;79:11457-11466.

171. Murphy FA, Coleman PH, Harrison AK, Gary GW. Colorado tick fever virus: an electron microscopic study. Virology 1968;35:28 40.

172. Isachkova LM, Shestopalova NM, Frolova MP, Reingold VN. Light and electron microscope study of the neurotropism of Powassan virus strain P-40. Acta Virol 1979;23:40-44.

173. Guo J. Studies using IPS cells support a possible link between ZIKA and microcephaly. Cell Biosci 2016;6:28.

174. Sirohi D, Chen Z, Sun L, et al. The $3.8 \AA$ resolution cryo-EM structure of Zika virus. Science 2016;352:467-470.

175. Tang H, Hammack C, Ogden SC, et al. Zika virus infects human cortical neural progenitors and attenuates their growth. Cell Stem Cell 2016;18:587-590.

176. Nowakowski TJ, Pollen AA, Di Lullo E, Sandoval-Espinosa C, Bershteyn M, Kriegstein AR. Expression analysis highlights AXL as a candidate Zika virus entry receptor in neural stem cells. Cell Stem Cell 2016;18:591-596.

177. Lee E, Lobigs M. Substitutions at the putative receptor-binding site of an encephalitic flavivirus alter virulence and host cell tropism and reveal a role for glycosaminoglycans in entry. J Virol 2000;74:8867-8875.

178. Davis NL, Grieder FB, Smith JF, et al. A molecular genetic approach to the study of Venezuelan equine encephalitis virus pathogenesis. Arch Virol Suppl 1994;9:99-109.

179. Lee E, Hall RA, Lobigs M. Common E protein determinants for attenuation of glycosaminoglycan-binding variants of Japanese encephalitis and West Nile viruses. J Virol 2004;78:8271-8280.

180. Aguilar PV, Adams AP, Wang E, et al. Structural and nonstructural protein genome regions of eastern equine encephalitis virus are determinants of interferon sensitivity and murine virulence. J Virol 2008;82:4920-4930.

181. Chen C-J, Ou Y-C, Lin S-Y, et al. Glial activation involvement in neuronal death by Japanese encephalitis virus infection. J Gen Virol 2010;91:1028-1037.

182. Cho H, Diamond MS. Immune responses to West Nile virus infection in the central nervous system. Viruses 2012;4:3812-3830.

183. Samuel MA, Morrey JD, Diamond MS. Caspase 3-dependent cell death of neurons contributes to the pathogenesis of West Nile virus encephalitis. J Virol 2007;81:2614-2623.

184. Růžek D, Vancová M, Tesařová M, Ahantarig A, Kopecký J, Grubhoffer L. Morphological changes in human neural cells following tick-borne encephalitis virus infection. J Gen Virol 2009;90:1649-1658

185. Jackson AC, Rossiter JP. Apoptotic cell death is an important cause of neuronal injury in experimental Venezuelan equine encephalitis virus infection of mice. Acta Neuropathol 1997;93:349 353.

186. Schoneboom BA, Catlin KMK, Marty AM, Grieder FB. Inflammation is a component of neurodegeneration in response to Venezuelan equine encephalitis virus infection in mice. $\mathrm{J}$ Neuroimmunol 2000;109:132-146.

187. Chambers TJ, Diamond MS. Pathogenesis of flavivirus encephalitis. Adv Virus Res 2003;60:273-342.

188. Yang J-S, Ramanathan MP, Muthumani K, et al. Induction of inflammation by West Nile virus capsid through the caspase- 9 apoptotic pathway. Emerg Infect Dis 2002;8:1379-1384.

189. Yang T-C, Shiu S-L, Chuang P-H, et al. Japanese encephalitis virus NS2B-NS3 protease induces caspase 3 activation and mitochondria-mediated apoptosis in human medulloblastoma cells. Virus Res 2009;143:77-85.

190. Prikhod'ko GG, Prikhod'ko EA, Pletnev AG, Cohen JI. Langat flavivirus protease NS3 binds caspase-8 and induces apoptosis. J Virol 2002;76:5701-5710.

191. Fredericksen BL, Keller BC, Fornek J, Katze MG, Gale M. Establishment and maintenance of the innate antiviral response to West Nile Virus involves both RIG-I and MDA5 signaling through IPS-1. J Virol 2008;82:609-616.

192. Mukherjee P, Woods TA, Moore RA, Peterson KE. Activation of the innate signaling molecule MAVS by bunyavirus infection upregulates the adaptor protein SARM1, leading to neuronal death. Immunity 2013;38:705-716.

193. Szretter KJ, Samuel MA, Gilfillan S, Fuchs A, Colonna M, Diamond MS. The immune adaptor molecule SARM modulates tumor necrosis factor alpha production and microglia activation in the brainstem and restricts West Nile virus pathogenesis. J Virol 2009;83:9329-9338.

194. Sharma A, Bhattacharya B, Puri RK, Maheshwari RK. Venezuelan equine encephalitis virus infection causes modulation of inflammatory and immune response genes in mouse brain. BMC Genomics 2008;9:289. 
195. Kumar M, Verma S, Nerurkar VR. Pro-inflammatory cytokines derived from West Nile virus (WNV)-infected SK-N-SH cells mediate neuroinflammatory markers and neuronal death. J Neuroinflammation 2010;7:73.

196. Guadagno J, Swan P, Shaikh R, Cregan SP. Microglia-derived IL$1 \beta$ triggers $p 53$-mediated cell cycle arrest and apoptosis in neural precursor cells. Cell Death Dis 2015;6:e1779.

197. Zou J, Wang Y-X, Dou F-F, et al. Glutamine synthetase downregulation reduces astrocyte protection against glutamate excitotoxicity to neurons. Neurochem Int 2010;56:577-584.

198. Palus M, Bílý T, Elsterová J, et al. Infection and injury of human astrocytes by tick-borne encephalitis virus. J Gen Virol 2014;95: 2411-2426.

199. Verma S, Kumar M, Nerurkar VR. Cyclooxygenase-2 inhibitor blocks the production of West Nile virus-induced neuroinflammatory markers in astrocytes. J Gen Virol 2011;92: 507-515.

200. Bhowmick S, Duseja R, Das S, Appaiahgiri MB, Vrati S, Basu A. Induction of IP-10 (CXCL10) in astrocytes following Japanese encephalitis. Neurosci Lett 2007;414:45-50.

201. Diniz JAP, Da Rosa APAT, Guzman H, et al. West Nile virus infection of primary mouse neuronal and neuroglial cells: the role of astrocytes in chronic infection. Am J Trop Med Hyg 2006;75: 691-696.

202. Ghoshal A, Das S, Ghosh S, et al. Proinflammatory mediators released by activated microglia induces neuronal death in Japanese encephalitis. Glia 2007;55:483-496.

203. Verma S, Kumar M, Gurjav U, Lum S, Nerurkar VR. Reversal of West Nile virus-induced blood-brain barrier disruption and tight junction proteins degradation by matrix metalloproteinases inhibitor. Virology 2010;397:130-138.

204. Schoneboom BA, Fultz MJ, Miller TH, McKinney LC, Grieder FB. Astrocytes as targets for Venezuelan equine encephalitis virus infection. J Neurovirol 1999;5:342-354.

205. Wang P, Dai J, Bai F, et al. Matrix metalloproteinase 9 facilitates West Nile virus entry into the brain. J Virol 2008;82:8978-8985.

206. Kreil TR, Eibl MM. Nitric oxide and viral infection: no antiviral activity against a flavivirusin vitro,and evidence for contribution to pathogenesis in experimental infection in vivo. Virology 1996;219:304-306

207. Andrews DM, Matthews VB, Sammels LM, Carrello AC, McMinn PC. The severity of murray valley encephalitis in mice is linked to neutrophil infiltration and inducible nitric oxide synthase activity in the central nervous system. J Virol 1999;73: 8781-8790.

208. Palus M, Vojtí̌ková J, Salát J, et al. Mice with different susceptibility to tick-borne encephalitis virus infection show selective neutralizing antibody response and inflammatory reaction in the central nervous system. J Neuroinflammation 2013;10:77.

209. McKimmie CS, Fazakerley JK. In response to pathogens, glial cells dynamically and differentially regulate Toll-like receptor gene expression. J Neuroimmunol 2005;169:116-125.

210. Verbruggen P, Ruf M, Blakqori G, et al. Interferon antagonist NSs of La Crosse virus triggers a DNA damage response-like degradation of transcribing RNA polymerase II. J Biol Chem 2011;286: 3681-3692.

211. Kato H, Takeuchi O, Sato S, et al. Differential roles of MDA5 and RIG-I helicases in the recognition of RNA viruses. Nature 2006;441:101-105.

212. Han YW, Choi JY, Uyangaa E, et al. Distinct dictation of Japanese encephalitis virus-induced neuroinflammation and lethality via triggering TLR3 and TLR4 signal pathways. PLoS Pathog 2014;10:e1004319.

213. Kindberg E, Vene S, Mickiene A, Lundkvist Å, Lindquist L, Svensson L. A functional Toll-like receptor 3 gene (TLR3) may be a risk factor for tick-borne encephalitis virus (TBEV) infection. J Infect Dis 2011;203:523-528.

214. Nazmi A, Mukherjee S, Kundu K, et al. TLR7 is a key regulator of innate immunity against Japanese encephalitis virus infection. Neurobiol Dis 2014;69:235-247.

215. Baker DG, Woods TA, Butchi NB, et al. Toll-like receptor 7 suppresses virus replication in neurons but does not affect viral pathogenesis in a mouse model of Langat virus infection. J Gen Virol 2013;94:336-347.

216. Sharma A, Maheshwari RK. Oligonucleotide array analysis of Toll-like receptors and associated signalling genes in Venezuelan equine encephalitis virus-infected mouse brain. J Gen Virol 2009;90:1836-1847.

217. Delhaye S, Paul S, Blakqori G, et al. Neurons produce type I interferon during viral encephalitis. Proc Natl Acad Sci U S A 2006;103:7835-7840.

218. Kallfass C, Ackerman A, Lienenklaus S, Weiss S, Heimrich B, Staeheli P. Visualizing production of beta interferon by astrocytes and microglia in brain of La Crosse virus-infected mice. J Virol 2012;86:11223-11230.

219. Binder GK, Griffin DE. Interferon-gamma-mediated site-specific clearance of alphavirus from CNS neurons. Science 2001;293: 303-306.

220. Binder GK, Griffin DE. Immune-mediated clearance of virus from the central nervous system. Microbes Infect Inst Pasteur 2003;5: 439-448.

221. Diamond MS, Shrestha B, Mehlhop E, Sitati E, Engle M. Innate and adaptive immune responses determine protection against disseminated infection by West Nile encephalitis virus. Viral Immunol 2003;16:259-278.

222. Sitati EM, Diamond MS. CD4+ T-cell responses are required for clearance of West Nile virus from the central nervous system. J Virol 2006;80:12060-12069.

223. Kimura-Kuroda J, Yasui K. Protection of mice against Japanese encephalitis virus by passive administration with monoclonal antibodies. J Immunol 1988;141:3606-3610.

224. Roehrig JT, Staudinger LA, Hunt AR, Mathews JH, Blair CD Antibody prophylaxis and therapy for flavivirus encephalitis infections. Ann N Y Acad Sci 2001;951:286-297.

225. Brandriss MW, Schlesinger JJ, Walsh EE, Briselli M. Lethal 17D yellow fever encephalitis in mice. I. Passive protection by monoclonal antibodies to the envelope proteins of 17D yellow fever and dengue 2 viruses. J Gen Virol 1986;67:229-234.

226. Ravi V, Parida S, Desai A, Chandramuki A, Gourie-Devi M, Grau GE. Correlation of tumor necrosis factor levels in the serum and cerebrospinal fluid with clinical outcome in Japanese encephalitis patients. J Med Virol 1997;51:132-136.

227. Burke DS, Lorsomrudee W, Leake CJ, et al. Fatal Outcome in Japanese Encephalitis. Am J Trop Med Hyg 1985;34:1203-1210.

228. Levine B, Hardwick JM, Trapp BD, Crawford TO, Bollinger RC, Griffin DE. Antibody-mediated clearance of alphavirus infection from neurons. Science 1991;254:856-860.

229. Dodd KA, McElroy AK, Jones MEB, Nichol ST, Spiropoulou CF. Rift Valley fever virus clearance and protection from neurologic disease are dependent on CD4+ T cell and virus-specific antibody responses. J Virol 2013;87:6161-6171.

230. Anderson GW, Lee JO, Anderson AO, Powell N, Mangiafico JA, Meadors G. Efficacy of a Rift Valley fever virus vaccine against an aerosol infection in rats. Vaccine 1991;9:710-714

231. Yun NE, Peng B-H, Bertke AS, et al. CD4+ T cells provide protection against acute lethal encephalitis caused by Venezuelan equine encephalitis virus. Vaccine 2009;27:4064-4073.

232. Brooke CB, Deming DJ, Whitmore AC, White LJ, Johnston RE. T cells facilitate recovery from Venezuelan equine encephalitis virus-induced encephalomyelitis in the absence of antibody. J Virol 2010;84:4556-4568. 
233. McCandless EE, Zhang B, Diamond MS, Klein RS. CXCR4 antagonism increases $\mathrm{T}$ cell trafficking in the central nervous system and improves survival from West Nile virus encephalitis. Proc Natl Acad Sci U S A 2008;105:11270-11275.

234. Zhang B, Chan YK, Lu B, Diamond MS, Klein RS. CXCR3 mediates region-specific antiviral $\mathrm{T}$ cell trafficking within the central nervous system during West Nile virus encephalitis. J Immunol 2008;180:2641-2649.

235. Durrant DM, Daniels BP, Klein RS. IL-1R1 signaling regulates CXCL12-mediated T cell localization and fate within the central nervous system during West Nile virus encephalitis. J Immunol 2014;193:4095-4106.

236. Shrestha B, Diamond MS. Role of CD8+ T cells in control of West Nile virus infection. J Virol 2004;78:8312-8321.

237. Murali-Krishna K, Ravi V, Manjunath R. Protection of adult but not newborn mice against lethal intracerebral challenge with Japanese encephalitis virus by adoptively transferred virusspecific cytotoxic T lymphocytes: requirement for L3T4+ T cells. J Gen Virol 1996;77:705-714.

238. Desai A, Murali-Krishna K, Ramireddy B, Ravi V, Manjunath R. In vivo clearance of Japanese encephalitis virus by adoptively transferred virus specific cytotoxic T lymphocytes. J Biosci 1997;22:33-45.

239. Wang Y, Lobigs M, Lee E, Müllbacher A. CD8+ T cells mediate recovery and immunopathology in West Nile virus encephalitis. J Virol 2003;77:13323-13334.

240. Lanteri MC, O'Brien KM, Purtha WE, et al. Tregs control the development of symptomatic West Nile virus infection in humans and mice. J Clin Invest 2009;119:3266-3277.

241. Gelpi E, Preusser M, Laggner U, et al. Inflammatory response in human tick-borne encephalitis: analysis of postmortem brain tissue. J Neurovirol 2006;12:322-327.

242. Růžek D, Salát J, Palus M, et al. CD8+ T-cells mediate immunopathology in tick-borne encephalitis. Virology 2009;384:1-6.

243. Brien JD, Uhrlaub JL, Nikolich-Zugich J. West Nile virus-specific CD4 T cells exhibit direct antiviral cytokine secretion and cytotoxicity and are sufficient for antiviral protection. J Immunol 2008;181:8568-8575.

244. Liu T, Chambers TJ. Yellow fever virus encephalitis: properties of the brain-associated T-cell response during virus clearance in normal and gamma interferon-deficient mice and requirement for CD4+ lymphocytes. J Virol 2001;75:2107-2118

245. Steele KE, Davis KJ, Stephan K, Kell W, Vogel P, Hart MK. Comparative neurovirulence and tissue tropism of wild-type and attenuated strains of Venezuelan equine encephalitis virus administered by aerosol in $\mathrm{C} 3 \mathrm{H} / \mathrm{HeN}$ and $\mathrm{BALB} / \mathrm{c}$ mice. Vet Pathol 1998;35:386-397.

246. Murray K, Baraniuk S, Resnick M, et al. Risk factors for encephalitis and death from West Nile virus infection. Epidemiol Infect 2006;134:1325-1332.

247. Mostashari F, Bunning ML, Kitsutani PT, et al. Epidemic West Nile encephalitis, New York, 1999: results of a household-based seroepidemiological survey. Lancet 2001;358:261-264.

248. Brien JD, Uhrlaub JL, Hirsch A, Wiley CA, Nikolich-Žugich J. Key role of T cell defects in age-related vulnerability to West Nile virus. J Exp Med 2009;206:2735-2745.

249. Kong K-F, Delroux K, Wang X, et al. Dysregulation of TLR3 impairs the innate immune response to West Nile virus in the elderly. J Virol 2008;82:7613-7623.

250. Xie G, Luo H, Pang L, et al. Dysregulation of Toll-like receptor 7 compromises innate and adaptive $\mathrm{T}$ cell responses and host resistance to an attenuated West Nile virus infection in old mice. J Virol 2015;90:1333-1344.

251. Das S, Basu A. Japanese encephalitis virus infects neural progenitor cells and decreases their proliferation. J Neurochem 2008;106: 1624-1636.
252. McJunkin JE, de los Reyes EC, Irazuzta JE, et al. La Crosse encephalitis in children. N Engl J Med 2001;344:801-807.

253. Castorena KM, Peltier DC, Peng W, Miller DJ. Maturationdependent responses of human neuronal cells to western equine encephalitis virus infection and type I interferons. Virology 2008;372:208-220.

254. Schultz KLW, Vernon PS, Griffin DE. Differentiation of neurons restricts arbovirus replication and increases expression of the alpha isoform of IRF-7. J Virol 2015;89:48-60.

255. Ryman KD, Gardner CL, Meier KC, Biron CA, Johnston RE, Klimstra WB. Early restriction of alphavirus replication and dissemination contributes to age-dependent attenuation of systemic hyperinflammatory disease. J Gen Virol 2007;88:518-529.

256. Miner JJ, Cao B, Govero J, et al. Zika virus infection during pregnancy in mice causes placental damage and fetal demise. Cell 2016 (in press)

257. Glass WG, McDermott DH, Lim JK, et al. CCR5 deficiency increases risk of symptomatic West Nile virus infection. J Exp Med 2006;203:35-40.

258. Kindberg E, Mickiene A, Ax C, et al. A deletion in the chemokine receptor 5 (CCR5) gene is associated with tickborne encephalitis. J Infect Dis 2008;197:266-269.

259. Lim JK, Lisco A, McDermott DH, et al. Genetic variation in OAS1 is a risk factor for initial infection with West Nile virus in man. PLoS Pathog 2009;5:e1000321.

260. Glass WG, Lim JK, Cholera R, Pletnev AG, Gao J-L, Murphy PM. Chemokine receptor CCR5 promotes leukocyte trafficking to the brain and survival in West Nile virus infection. J Exp Med 2005;202:1087-1098.

261. Bigham AW, Buckingham KJ, Husain S, et al. Host genetic risk factors for West Nile virus infection and disease progression. PLoS ONE 2011;6:e24745.

262. Barkhash AV, Perelygin AA, Babenko VN, et al. Variability in the 2'-5'-oligoadenylate synthetase gene cluster is associated with human predisposition to tick-borne encephalitis virus-induced disease. J Infect Dis 2010;202:1813-1818.

263. Case KL, West RM, Smith MJ. Histocompatibility antigens and La Crosse encephalitis. J Infect Dis 1993;168:358-360.

264. Dutta K, Basu A. Use of minocycline in viral infections. Indian J Med Res 2011;133:467-470.

265. Mishra MK, Ghosh D, Duseja R, Basu A. Antioxidant potential of minocycline in Japanese Encephalitis virus infection in murine neuroblastoma cells: correlation with membrane fluidity and cell death. Neurochem Int 2009;54:464-470.

266. Das S, Dutta K, Kumawat KL, Ghoshal A, Adhya D, Basu A. Abrogated inflammatory response promotes neurogenesis in a murine model of Japanese encephalitis. PLoS One 2011;6:e17225.

267. Kumar R, Basu A, Sinha S, et al. Role of oral minocycline in acute encephalitis syndrome in India - a randomized controlled trial. BMC Infect Dis 2016;16:67.

268. Swarup V, Ghosh J, Mishra MK, Basu A. Novel strategy for treatment of Japanese encephalitis using arctigenin, a plant lignan. J Antimicrob Chemother 2008;61:679-688.

269. Sehgal N, Kumawat KL, Basu A, Ravindranath V. Fenofibrate reduces mortality and precludes neurological deficits in survivors in murine model of Japanese encephalitis viral infection. PLoS One 2012; 7:e35427.

270. Dutta K, Ghosh D, Basu A. Curcumin protects neuronal cells from Japanese encephalitis virus-mediated cell death and also inhibits infective viral particle formation by dysregulation of ubiquitinproteasome system. J Neuroimmune Pharmacol 2009;4:328-337.

271. Centers for Disease Control and Prevention (CDC). Recommendations of the Advisory Committee on Immunization Practices (ACIP). Inactivated Japanese encephalitis virus vaccine. MMWR 1993;42:1-15. 
272. Anon. A new Japanese encephalitis vaccine (Ixiaro). Med Lett Drugs Ther 2009;51:66-67.

273. Jelinek T. Ixiaro: a new vaccine against Japanese encephalitis. Expert Rev Vaccines 2009;8:1501-1511.

274. Meningococcal vaccines: polysaccharide and polysaccharide conjugate vaccines. Wkly Epidemiol Rec 2002;77:331-339.

275. Quicke KM, Suthar MS. The innate immune playbook for restricting West Nile virus infection. Viruses 2013;5:2643-2658.

276. Kalil AC, Devetten MP, Singh S, et al. Use of interferon-alpha in patients with West Nile encephalitis: report of 2 cases. Clin Infect Dis 2005;40:764-766.

277. Chan-Tack KM, Forrest G. Failure of interferon alpha-2b in a patient with West Nile virus meningoencephalitis and acute flaccid paralysis. Scand J Infect Dis 2005;37:944-946.

278. Amanna IJ, Raué H-P, Slifka MK. Development of a new hydrogen peroxide-based vaccine platform. Nat Med 2012;18:974979.

279. Cassidy LF, Patterson JL. Mechanism of La Crosse virus inhibition by ribavirin. Antimicrob Agents Chemother 1989;33:20092011.

280. McJunkin JE, Khan R, de los Reyes EC, et al. Treatment of severe La Crosse encephalitis with intravenous ribavirin following diagnosis by brain biopsy. Pediatrics 1997;99:261-267.

281. Haddow AD, Haddow AD. The use of oral ribavirin in the management of La Crosse viral infections. Med Hypotheses 2009;72: 190-192.

282. McJunkin JE, Nahata MC, De Los Reyes EC, et al. Safety and pharmacokinetics of ribavirin for the treatment of la crosse encephalitis. Pediatr Infect Dis J 2011;30:860-865.

283. Paessler S, Weaver SC. Vaccines for Venezuelan equine encephalitis. Vaccine 2009;27(Suppl. 4):D80-D85.

284. Pittman PR, Makuch RS, Mangiafico JA, Cannon TL, Gibbs PH, Peters CJ. Long-term duration of detectable neutralizing antibodies after administration of live-attenuated VEE vaccine and following booster vaccination with inactivated VEE vaccine. Vaccine 1996;14:337-343.

285. Martin SS, Bakken RR, Lind CM, et al. Evaluation of formalin inactivated V3526 virus with adjuvant as a next generation vaccine candidate for Venezuelan equine encephalitis virus. Vaccine 2010;28:3143-3151.

286. Shrestha B, Gottlieb D, Diamond MS. Infection and Injury of neurons by West Nile encephalitis virus. J Virol 2003;77:1320313213.

287. Liu Y, King N, Kesson A, Blanden RV, Müllbacher A. West Nile virus infection modulates the expression of class I and class II MHC antigens on astrocytes in vitro. Ann N Y Acad Sci 1988;540:483-485.

288. Chen CJ, Liao SL, Kuo MD, Wang YM. Astrocytic alteration induced by Japanese encephalitis virus infection. Neuroreport 2000;11:1933-1937.
289. Desai A, Shankar SK, Ravi V, Chandramuki A, GourieDevi M. Japanese encephalitis virus antigen in the human brain and its topographic distribution. Acta Neuropathol 1995;89:368-373.

290. Chang C-Y, Li J-R, Chen W-Y, et al. Disruption of in vitro endothelial barrier integrity by Japanese encephalitis virus-Infected astrocytes. Glia 2015 May 8 [Epub ahead of print].

291. Reyes MG, Gardner JJ, Poland JD, Monath TP. St Louis encephalitis. Quantitative histologic and immunofluorescent studies. Arch Neurol 1981;38:329-334.

292. Cho H, Proll SC, Szretter KJ, Katze MG, Gale M, Diamond MS Differential innate immune response programs in neuronal subtypes determine susceptibility to infection in the brain by positive stranded RNA viruses. Nat Med 2013;19:458-464.

293. Mázló M, Szántó J. Morphological demonstration of the virus of tick-borne encephalitis in the human brain. Acta Neuropathol 1978;43:251-253.

294. Dropulić B, Masters CL. Entry of neurotropic arboviruses into the central nervous system: an in vitro study using mouse brain endothelium. J Infect Dis 1990;161:685-691.

295. Yin J, Gardner CL, Burke CW, Ryman KD, Klimstra WB Similarities and differences in antagonism of neuron alpha/beta interferon responses by Venezuelan equine encephalitis and Sindbis alphaviruses. J Virol 2009;83:10036-10047.

296. Kehn-Hall K, Narayanan A, Lundberg L, et al. Modulation of GSK-3 $\beta$ activity in Venezuelan equine encephalitis virus infection. PLoS One 2012;7:e34761.

297. Roy CJ, Reed DS, Wilhelmsen CL, Hartings J, Norris S, Steele KE. Pathogenesis of aerosolized Eastern Equine Encephalitis virus infection in guinea pigs. Virol J 2009;6:170.

298. Pekosz A, Phillips J, Pleasure D, Merry D, Gonzalez-Scarano F. Induction of apoptosis by La Crosse virus infection and role of neuronal differentiation and human bcl-2 expression in its prevention. J Virol.1996;70:5329-5335.

299. Reed C, Steele KE, Honko A, Shamblin J, Hensley LE, Smith DR. Ultrastructural study of Rift Valley fever virus in the mouse model. Virology 2012;431:58-70.

300. Smith DR, Steele KE, Shamblin J, et al. The pathogenesis of Rift Valley fever virus in the mouse model. Virology 2010;407:256-267.

301. Moy RH, Gold B, Molleston JM, et al. Antiviral autophagy restrictsRift Valley fever virus infection and is conserved from flies to mammals. Immunity 2014;40:51-65.

302. Frolova MP, Isachkova LM, Shestopalova NM, Pogodina VV. Experimental encephalitis in monkeys caused by the Powassan virus. Neurosci Behav Physiol 1985;15:62-69.

303. Gholam BI, Puksa S, Provias JP. Powassan encephalitis: a case report with neuropathology and literature review. CMAJ 1999;161:1419-1422. 